\title{
ER $\alpha$ Signaling Is Required for TrkB-Mediated Hippocampal Neuroprotection in Female Neonatal Mice after Hypoxic Ischemic Encephalopathy ${ }^{1,2,3}$
}

\author{
Ulas Cikla, ${ }^{1,2}$ Vishal Chanana, ${ }^{1}$ Douglas B. Kintner, ${ }^{1}$ EDshwar Udho, ${ }^{1}$ Jens Eickhoff, ${ }^{3}$ ' Wendy Sun, ${ }^{1}$ \\ Stephanie Marquez, ${ }^{1}$ Lucia Covert, ${ }^{1}$ Arel Otles, ${ }^{1}$ (1) Robert A. Shapiro, ${ }^{4}$ Peter Ferrazzano, ${ }^{1,5}$ Raghu \\ Vemuganti, ${ }^{2}$ Jon E. Levine, ${ }^{4}$ and ${ }^{-}$Pelin Cengiz ${ }^{1,5}$
}

\section{DOI:http://dx.doi.org/10.1523/ENEURO.0025-15.2015}

\begin{abstract}
${ }^{1}$ Waisman Center, University of Wisconsin School of Medicine and Public Health, Madison, Wisconsin 53705, ${ }^{2}$ Department of Neurological Surgery, University of Wisconsin School of Medicine and Public Health, Madison, Wisconsin 53792, ${ }^{3}$ Department of Statistics and Bioinformatics, University of Wisconsin School of Medicine and Public Health, Madison, Wisconsin 53792, ${ }^{4}$ Department of Neuroscience, University of Wisconsin School of Medicine and Public Health, Madison, Wisconsin 53705, and ${ }^{5}$ Department of Pediatrics, University of Wisconsin School of Medicine and Public Health, Madison, Wisconsin 53792
\end{abstract}

\begin{abstract}
Male neonate brains are more susceptible to the effects of perinatal asphyxia resulting in hypoxia and ischemia $(\mathrm{HI})$-related brain injury. The relative resistance of female neonatal brains to adverse consequences of $\mathrm{HI}$ suggests that there are sex-specific mechanisms that afford females greater neuroprotection and/or facilitates recovery post-HI. We hypothesized that $\mathrm{HI}$ preferentially induces estrogen receptor $\alpha(\mathrm{ER} \alpha)$ expression in female neonatal hippocampi and that $\mathrm{ER} \alpha$ is coupled to Src family kinase (SFK) activation that in turn augments phosphorylation of the TrkB and thereby results in decreased apoptosis. After inducing the Vannucci's HI model on P9 (C57BL/6J) mice, female and male $\mathrm{ER} \alpha$ wild-type $\left(\mathrm{ER} \alpha^{+/+}\right)$or $\mathrm{ER} \alpha$ null mutant $\left(\mathrm{ER} \alpha^{-/-}\right)$mice received vehicle control or the selective TrkB agonist 7,8-dihydroxyflavone (7,8-DHF). Hippocampi were collected for analysis of mRNA of ER $\alpha$ and $\mathrm{BDNF}$, protein levels of $\mathrm{ER} \alpha, \mathrm{p}$-TrkB, p-src, and cleaved caspase 3 (c-caspase-3) post-HI. Our results demonstrate that: (1) $\mathrm{HI}$ differentially induces $\mathrm{ER} \alpha$ expression in the hippocampus of the female versus male neonate, (2) src and TrkB phosphorylation post-HI is greater in females than in males after 7,8-DHF therapy, (3) src and TrkB phosphorylation post-HI depend on the presence of $\mathrm{ER} \alpha$, and (4) TrkB agonist therapy decreases the c-caspase-3 only in ER $\alpha^{+/+}$female mice hippocampus. Together, these observations provide evidence that female-specific induction of ER $\alpha$ expression confers neuroprotection with TrkB agonist therapy via SFK activation and account for improved functional outcomes in female neonates post-HI.
\end{abstract}

Key words: 7,8-dihydroxyflavone; estrogen receptor alpha; hypoxia-ischemia; neonate; src; tyrosine kinase B

\section{Significance Statement}

Female neonate brains are more resistant to the effects of hypoxia-ischemia (HI). We report a novel mechanism that involves the female-biased induction of ER $\alpha$ expression in the hippocampus post-HI, coupled to activation of a cytoplasmic kinase (src) and increased TrkB phosphorylation in the presence of a TrkB agonist. Thus, the enhanced TrkB receptor signaling resulting from this crosstalk mechanism confers decreased programmed cell death in response to TrkB agonist treatment in female versus male subjects. These results clearly demonstrate a role for $\mathrm{ER} \alpha$ in enhancing TrkB activation and may account for the relative resistance of the female neonate brain to $\mathrm{HI}$. 


\section{Introduction}

Perinatal asphyxia resulting in hypoxia-ischemia (HI)related brain injury leads to severe, life-long morbidities in thousands of neonates and children born in the U.S. each year (Ferriero, 2004; Nelson and Lynch, 2004; Drobyshevsky et al., 2007; Hill and Fitch, 2012). The physical, emotional, and economic toll taken by these adverse early childhood events is incalculable. Interestingly, clinical studies indicate that male neonate brains are more susceptible to the effects of perinatal asphyxia (Vannucci and Hurn, 2009; Hill and Fitch, 2012) resulting in greater longterm cognitive deficits compared with females with comparable brain injury (Marlow et al., 2005; Tioseco et al., 2006; Hill and Fitch, 2012). In addition, males show increased risk for brain-based developmental disorders including learning disabilities and cerebral palsy compared with females (Donders and Hoffman, 2002; Rutter et al., 2003). The relative resistance of female neonatal brain to adverse consequences of $\mathrm{HI}$ suggests that there are sexspecific mechanisms that afford females greater neuroprotection and/or facilitates recovery post-HI (Rutter et al., 2003; Hill and Fitch, 2012). Understanding these mechanisms will help identify sex-specific therapeutic interventions following perinatal $\mathrm{HI}$ and lead to better neurological outcomes.

One possible mechanism that could contribute to the sex-based outcomes is differences seen in the expression of estrogen receptors post-HI. Experimental studies have shown that estrogen receptor $\alpha(E R \alpha)$ plays an essential role in the sexual differentiation of neurons in mammalian brain (Simerly et al., 1997) and increased hippocampal expression of ER $\alpha$ results in improvement of memory and learning in aging females long after estradiol $\left(E_{2}\right)$ therapy is terminated (Witty et al., 2013). In adult female brain after middle cerebral artery occlusion (MCAO), ER $\alpha$ expression is differentially increased at the ischemia site (Wilson et al., 2011). However, the question of whether $\mathrm{ER} \alpha$ plays

Received March 9, 2015; accepted December 23, 2015; First published January 12, 2016.

${ }^{1}$ The authors report no conflict of interest.

${ }^{2}$ Author contributions: U.C., V.C., D.B.K., E.U., W.S., S.M., L.C., A.O., and P.C. performed research; U.C., V.C., D.B.K., J.E., and P.C. analyzed data; U.C., D.B.K., J.E.L., and P.C. wrote the paper; R.A.S., P.F., R.V., J.E.L., and P.C. designed research.

${ }^{3}$ This work was supported by a University of Wisconsin Department of Pediatrics Research \& Development Grant (P.C.), Clinical and Translational Science Award program of NCATS UL1 TR0000427 and KL2 TR000428 (P.C.), UL1TR000427 to the UW ICTR from NIH/NCATS and funds from Waisman Center (P.C.), NIH/NINDS K08NS088563-01A1 (P.C.) and NIH P30 HD03352 (Waisman Center), NIH/NINDS 1K08NS078113 (P.F.). We thank Drs John Svaren and Matthew Flowers for invaluable technical support that they provided for the qPCR experiments and chemiluminescence imaging, respectively.

Correspondence should be addressed to Dr Pelin Cengiz, Department of Pediatrics, University of Wisconsin-Madison, School of Medicine and Public Health, Waisman Center T505, Madison, WI 53705. E-mail address: cengiz@pediatrics.wisc.edu.

DOI:http://dx.doi.org/10.1523/ENEURO.0025-15.2015

Copyright @ 2016 Cikla et al.

This is an open-access article distributed under the terms of the Creative Commons Attribution 4.0 International, which permits unrestricted use, distribution and reproduction in any medium provided that the original work is properly attributed. a role in sex differences seen in neonatal brains post-HI has not been investigated.

The development and survival of the mammalian nervous system is largely dependent on the existence of soluble neurotrophic factors. One example is BDNF whose function is primarily mediated through the highaffinity cell-surface receptor TrkB. In the CNS, TrkB is widely expressed in neurons and contributes to diverse biological processes including neuronal survival and neuronal differentiation (Huang and Reichardt, 2001). Following stroke, BDNF signaling through TrkB has been shown to provide neuroprotection through a variety of mechanisms that include neurogenesis and most notably facilitation of anti-apoptosis signaling (Chen et al., 2013). Administration of the BDNF provides neuroprotection in neonatal rats post-HI (Almli et al., 2000) and in excitotoxic lesions resulting in white matter damage in neonates (Husson et al., 2005). Unfortunately, the poor bioavailability of BDNF limits its potential use in clinical trials as a therapeutic intervention (Thorne and Frey, 2001). Alternative small molecules with intrinsic neurotrophic activities and improved bioavailability have promising translational potentials for neuroprotection after brain injury. One example to these small molecules is the selective TrkB agonist, 7,8-dihydroxyflavone (7,8-DHF; Jang et al., 2010). This selective agonist crosses the blood--brain barrier when administered systemically, and provides neuroprotection in MCAO model of adult mice (Jang et al., 2010). In addition, systemically administered 7,8-DHF exerts a profound hippocampal neuroprotection in female but not male mice after perinatal HI (Uluc et al., 2013). It was proposed that this sex-specific neuroprotection was due to the increases in TrkB phosphorylation in female hippocampi.

Estrogen, through its membrane receptor ER $\alpha$ and shared signaling pathways can modulate the actions of BDNF and TrkB in the hippocampus (Scharfman and Maclusky, 2005). Further evidence of an $\mathrm{ER} \alpha /$ TrkB link is provided by the finding that, whereas $E_{2}$ therapy induces phosphorylation of TrkB in the adult mouse hippocampus the response is absent in $\mathrm{ER} \alpha^{-1-}$ mice (Spencer-Segal et al., 2012). In addition, membrane associated $\mathrm{ER} \alpha$ is coupled to the Src family of intracellular kinases called Src family kinases (SFK) and has been shown to facilitate the phosphorylation and activation of TrkB (Barletta et al., 2004; Arpino et al., 2008; Huang and McNamara, 2010). These studies prompted us to study the interaction of $\mathrm{ER} \alpha$ and TrkB in the neonatal mice hippocampus post-HI to identify the mechanisms resulting in relative resistance of female neonatal brain to $\mathrm{HI}$ and facilitating recovery.

We report a novel mechanism for sexually differentiated hippocampal neuroprotection and identify a potential crosslink between ER $\alpha$ and TrkB in neonatal mice hippocampus post-HI. Our studies test the hypothesis that $\mathrm{HI}$ in female neonatal hippocampus preferentially induces ER $\alpha$ expression resulting in sexually differentiated phosphorylation of the TrkB and decreasing apoptosis, with SFK functioning as an intermediary step providing crosstalk between $\mathrm{ER} \alpha$ and TrkB. 


\section{Materials and Methods}

\section{Materials}

Mouse microtubule associated protein 2 (MAP2) antibody, goat serum, and 7,8-DHF were obtained from Sigma-Aldrich. Rabbit polyclonal anti-phospho-src (Y418), rabbit polyclonal anti-phospho-TrkB (Y515) and rabbit anticleaved caspase 3 for immunohistochemistry were purchased from Abcam. Rabbit polyclonal phospho-TrkB (Y705) for immunoblotting was obtained from Signalway Antibody. Rabbit polyclonal anti-TrkB for immunoblotting and mouse monoclonal anti-neuronal nuclei (NeuN) for immunohistochemistry were obtained from EMD Millipore. Rabbit monoclonal anti-src for immunoblotting and rabbit polyclonal anti-cleaved caspase 3 (Asp 175) were obtained from Cell Signaling. Rabbit anti-ER $\alpha$ (MC-20) for immunoblotting was obtained from Santa Cruz Biotechnology. Mouse anti- $\beta$-actin was obtained from Developmental Studies Hybridoma Bank. Vectashield mounting media with DAPI was purchased from Vector Laboratories. Goat anti-mouse AlexaFluor 488-conjugated IgG, goat anti-rabbit AlexaFluor 546-conjugated IgG, PlatinumTaq Master Mix, Trizol, Purelink, PCR master mix, TaqMan probes for $\mathrm{ER} \alpha$, ER $\beta$, BDNF and $\beta$-actin, trypsinEDTA, HBSS, horse serum, penicillin/streptomycin, neurobasal medium, and B-27 medium were obtained from Life Technologies.

\section{Animal use}

All procedures on animals were carried out in adherence with the NIH Guide for the Care and Use of Laboratory Animals using protocols reviewed by the Institutional Animal Care and Use Committee at our institution.

\section{Genotyping}

$\mathrm{ER} \alpha$ heterogeneous $\left(\mathrm{ER} \alpha^{+/-}\right)$C57BL/6J mice were bred and pups were sexed and genotyped within $9 \mathrm{~d}$ of birth. Genotypes were determined by PCR of genomic DNA from finger or toe clippings. Clippings were heated at $95^{\circ} \mathrm{C}$ for $45 \mathrm{~min}$ in $50 \mathrm{~mm} \mathrm{NaOH}$ and neutralized with equal volume of $1 \mathrm{M}$ Tris, $\mathrm{pH}$ 6.8. One microliter of this DNA solution was added to $19 \mu \mathrm{L}$ of the following: 0.25 $\mu \mathrm{M}$ of primers for the ER $\alpha$ gene, $1 \times$ GoTaq Buffer (Promega), $0.2 \mathrm{~mm}$ each deoxynucleotide (Promega) and $8 \mathrm{U}$ Platinum Taq (Life Technologies). PCR was performed for 30 cycles as follows: $95^{\circ} \mathrm{C}$ for $3 \mathrm{~min}$, denaturation at $95^{\circ} \mathrm{C}$ for $30 \mathrm{~s}$, annealing at $58^{\circ} \mathrm{C}$ for $30 \mathrm{~s}\left(\mathrm{ER} \alpha^{-1-} \mathrm{PCR} 1\right)$ or $51^{\circ} \mathrm{C}$ for $30 \mathrm{~s}$ (ER $\left.\alpha^{-1-} \mathrm{PCR} 2\right)$, and elongation at $72^{\circ} \mathrm{C}$ for $1 \mathrm{~min}$. PCR products were separated electrophoretically on an ethidium bromide-containing $2 \%$ agarose gel and visualized under UV illumination.

\section{Induction of neonatal HI}

$\mathrm{HI}$ was induced as previously described with some modification (Vannucci and Vannucci, 1997). Postnatal day $(P) 9$ C57BL/6J mice were anesthetized with isofluorane (Butler Schein Animal Health Supply; 3\% for induction, $1.5 \%$ for maintenance) in 2:1 nitrous oxide-oxygen. The body temperature of the pups were maintained at $36^{\circ} \mathrm{C}$ using a heated surgical table (Molecular Imaging Products). Under a surgical microscope (Nikon SMZ-800
Zoom Stereo, Nikon), a midline skin incision was made and the muscle overlying the trachea visualized. The left common carotid artery was freed from the carotid sheath by blunt dissection, electrically cauterized, and cut. The incision was injected with $0.5 \%$ bupivacaine and closed with a single 6.0 silk suture. Animals were returned to their dams and monitored continuously for a $2 \mathrm{~h}$ recovery period. To induce unilateral ischemic injury, the animals were placed in a hypoxia chamber (BioSpherix) equilibrated with $10 \% \mathrm{O}_{2}$ and $90 \% \mathrm{~N}_{2}$ at $36^{\circ} \mathrm{C}$ for $50 \mathrm{~min}$. After $\mathrm{HI}$, animals were returned to their dams and monitored for pain and discomfort every minute for the first $30 \mathrm{~min}$, every 30 min for the next $2 \mathrm{~h}$, and then daily until sacrificed. This is a well-characterized model of neonatal $\mathrm{HI}$ and results in reproducible brain injury ipsilateral (IL) to the electrocauterized left common carotid artery(Vannucci and Vannucci, 1997; Cengiz et al., 2011; Uluc et al., 2013). In this model, unilateral severing of common carotid artery alone does not induce ischemic injury due to collateral circulation from the contralateral (CL) side through the circle of Willis. Only subsequent exposure to hypoxia results in hemispheric ischemia as a result of the preferential decrease of blood flow to the ipsilateral (IL) hemisphere secondary to hypocarbia (Mujsce et al., 1990).

Sham-operated mice received anesthesia and exposure of the left common carotid artery without electrocauterization or hypoxia, as described in this model before (Fang et al., 2013).

\section{Drug administration}

In vivo: male and female littermates were randomly divided into HI-vehicle control and $\mathrm{HI}+7,8-\mathrm{DHF}$ therapy groups. The $\mathrm{HI}+7,8-\mathrm{DHF}$-treated groups received the initial dose of $7,8-\mathrm{DHF}$ (5 mg/kg, i.p.) diluted in $0.1 \mathrm{M}$ PBS at $10 \mathrm{~min}$ after HI. Subsequently, mice were given a daily dose for $2 \mathrm{~d}$ after $\mathrm{HI}$. The HI-vehicle control groups received an equal volume of PBS at the same time points.

\section{Brain tissue preparation}

On day 3 (P12) or day 1 (P10) post-HI, animals were either decapitated for collection of fresh tissue or perfusion fixed in situ. For perfusion fixation, the animals were anesthetized with isoflurane as described and transcardially perfused with $4 \%$ paraformaldehyde and decapitated. After postfixation of the brains in $4 \%$ paraformaldehyde overnight, brains were stored in a $30 \%$ sucrose/PBS solution for $48 \mathrm{~h}$ and then sectioned $(35 \mu \mathrm{m}$ thick) on a freezing sliding microtome (Leica SM2000R). The brain sections were then cryoprotected in an antifreeze solution for storage at $-20^{\circ} \mathrm{C}$.

\section{Double-immunofluorescence staining}

After rinsing with $0.1 \mathrm{M}$ Tris-buffered saline (TBS), brain slices were incubated with $\mathrm{TBS}^{++}(0.1 \%$ Triton X-100 and $3 \%$ goat serum in $0.1 \mathrm{M} \mathrm{TBS})$ for $30 \mathrm{~min}$ at $37^{\circ} \mathrm{C}$. Slices were double-stained with anti-MAP2 (1:500) and anti$\mathrm{p}-T r k B^{\mathrm{Y} 515}(1: 100)$ or anti-cleaved caspase $3(1: 200)$ and anti-NeuN (1:200), or anti-p-src ${ }^{Y 418}(1: 250)$ and anti$\operatorname{NeuN}(1: 200)$, for $1 \mathrm{~h}$ at $37^{\circ} \mathrm{C}$ and then overnight at $4^{\circ} \mathrm{C}$. After washing with TBS $(3 \times 10 \mathrm{~min})$, brain sections were incubated for $1 \mathrm{~h}$ at $37^{\circ} \mathrm{C}$ with goat anti-rabbit AlexaFluor 
488-conjugated IgG (1:200) and goat anti-mouse AlexaFluor 546-conjugated IgG (1:200) in $\mathrm{TBS}^{++}$. Following rinsing with TBS, the slices were mounted on slides using Vectashield mounting media with DAPI. Primary antibodies were eliminated in some slices to control for nonspecific secondary antibody staining. Slides were imaged with either a Nikon A1R-Si confocal microscope using a $20 \times$ objective or whole-brain images collected with a Zeiss epifluorescent microscope using a $5 \times$ objective and Stereo Investigator software (MBF Bioscience).

\section{Quantification of pTrkB immunofluorescence staining}

To semi-quantitate $\mathrm{pTrkB}^{\mathrm{Y} 515}$ staining, whole-brain images were imported into Image $\mathrm{J}$ software (Schneider et al., 2012) and a region-of-interest was drawn around the $C L$ and IL hippocampus. The mean pixel values for the $\mathrm{CL}$ and IL region of interests were subtracted from background pixel values and expressed as the IL/CL ratio. Three slices through the hippocampi from each brain were analyzed and the IL/CL ratios averaged.

\section{Immunoblotting}

The hippocampal protein expression of total TrkB, $\mathrm{p}$-TrkB ${ }^{\mathrm{Y} 705}$, total src, $\mathrm{p}$-src ${ }^{\Upsilon 418}$, and $\mathrm{ER} \alpha$ at $3 \mathrm{~d}$ and cleaved caspase-3 (c-caspase-3) at $1 \mathrm{~d}$ post-HI were quantified. The $\mathrm{CL}$ and IL hippocampi from two brains were harvested and pooled in order to achieve the adequate protein content. The tissues were homogenized and centrifuged at $2200 \times g$ for $5 \mathrm{~min}$ at $4^{\circ} \mathrm{C}$. The protein content was determined by the bicinchionic acid method (Pierce). The protein samples $(50 \mu \mathrm{g})$ and pre-stained molecular mass markers in a SDS buffer were electrophoretically separated on $4-20 \%$ gradient SDS gels. The resolved proteins were electrophoretically transferred to a nitrocellulose membrane. After incubation in 5\% nonfat dry milk in TBS for $1 \mathrm{~h}$, the blots were probed with the anti-TrkB antibody $(1: 1000)$ and anti-p-TrkB ${ }^{\mathrm{Y} 705}$ antibody (1:800); or anti-t-src $(1: 1000)$ and anti-p-src ${ }^{\mathrm{Y} 418}(1: 800)$; or anti-ER $\alpha$ (1:500) and $\beta$-actin (1:2000); or c-caspase-3 $(1: 800)$ and $\beta$-actin $(1: 2000)$ overnight at $4^{\circ} \mathrm{C}$. After rinsing with TBS, the blots were incubated with goat anti-rabbit horseradish peroxidase-conjugated secondary $\lg$ (1: $6000)$ or rabbit anti-mouse horseradish peroxidaseconjugated secondary IgG (1:6000) for $1 \mathrm{~h}$. Bound antibodies were visualized using an enhanced chemiluminescence assay (Millipore or Biorad).

\section{Quantitative PCR}

CL and IL hippocampi were freshly harvested and immediately placed on dry ice. Total RNA was extracted from single hippocampi using Trizol and a Purelink kit from Life Technologies. The amount of total RNA was determined from the optical densities measurements at 260 and $280 \mathrm{~nm}$ (Nanodrop, Thermo Scientific). The reverse transcription reaction (RT) was performed using SuperScript III reverse-transcription reagents and protocols from Life Technologies. Two micrograms of total RNA, random hexamers, oligdTs, dNTPS, and RT buffer were heated for $10 \mathrm{~min}$ at $65^{\circ}$ for denaturation. First Strand Buffer, DTT, RNAase inhibitor, and the superscript reverse III transcriptase were then added and the samples heated up to $42^{\circ} \mathrm{C}$ for $1 \mathrm{~h}$ followed by $5 \mathrm{~min}$ at $95^{\circ} \mathrm{C}$ to inactivate the reverse transcriptase. The resulting cDNA samples were then diluted 1:10 with RNAase free water and stored at $-80^{\circ} \mathrm{C}$ until use. For quantitative PCR (qPCR) amplification $\sim 20 \mathrm{ng}$ of cDNA was used. Each reaction (final volume $19 \mu \mathrm{l}$ ) for a single gene was done in duplicate and consisted of predesigned gene-specific primers and probes for ER $\alpha$ (Mn00433149_m1), ER $\beta$ (Mm00599821_m1), BDNF (Mm04230607_s1), or $\beta$-actin (Mm00607969_s1) and TaqMan Master Mix on a 96-well plate. PCR amplification was accomplished using an Applied Biosystem 7500 qPCR system (Life Technologies) running a standard amplification protocol $\left(50^{\circ} \mathrm{C} 2 \mathrm{~min}\right.$, $95^{\circ} \mathrm{C} 10 \mathrm{~min}, 95^{\circ} \mathrm{C} 15 \mathrm{sec}, 60^{\circ} \mathrm{C} 1 \mathrm{~min}, 40$ cycles). Relative gene expression was calculated by the $2^{-\Delta \Delta C}$ method (relative to female $\mathrm{CL}$ ) or a standard curve for the control gene ( $\beta$-actin) was obtained by serial 1:10 dilution of the cDNA from the female CL hippocampus and the undiluted sample assigned a value of 1 . Cycles to threshold values were analyzed using the System 7500 SDS software (Life Technologies). The calculated values were normalized to their corresponding $\beta$-actin values and expressed relative to the value for the female CL hippocampus.

\section{Statistical analysis}

ANCOVA was used to evaluate the effect of sex, $\mathrm{HI}$, and $7,8-\mathrm{DHF}$ therapy on all immunoblot band density parameters $(p-T r k B$ Y705/f-TrkB, $f$-TrkB/ $\beta$-actin, $t$-TrkB/ $\beta$-actin, $\mathrm{i}$-TrkB/ $\beta$-actin, $\mathrm{p}$-src ${ }^{\mathrm{Y} 418} / \mathrm{t}$-src, and $\mathrm{c}$-caspase- $3 / \beta$-actin). The primary outcome variables were the immunoblot band density parameters from the IL side. The analyses were adjusted by including the corresponding $C L$ side values as covariates in the model. Thus, in these figures we report the adjusted IL mean \pm SEM. The main and interaction effects between factors were evaluated. $p$ values were calculated from the corresponding $F$ values of the main or interaction effects. The comparisons of the outcome parameters between males and females were made by constructing sliced contrast matrices of the corresponding two- or three-way interaction effects. Analogously, ANCOVA was conducted to evaluate the sex effect for $\mathrm{HI}$ treated subjects on BDNF and ER $\alpha$ expression levels. The results were presented using bar charts displaying the adjusted means and corresponding standard error bars. Analysis of variance was performed to evaluate the effects of sex and mutation status on the percentage change in the IL/CL ratio of hippocampal pTrkB ${ }^{\mathrm{Y705}}$ staining levels. All $p$ values are two-sided and $p<0.05$ was used to define statistical significance. Statistical analyses were conducted using SAS software (SAS Institute) version 9.3 (Table 1).

\section{Results}

\section{$\mathrm{HI}$ induces increased ER $\alpha$ mRNA and protein expressions in female but not in male hippocampi}

$\mathrm{ER} \alpha \mathrm{mRNA}$ and protein expression were increased in the ischemic cortex of ovariectomized adult female rats, but were unchanged in adult males in an MCAO model (Westberry et al., 2008; Wilson and Westberry, 2009). However, 
Table 1. Statistical table

\begin{tabular}{llll}
\hline & Data structure & Type of test & $95 \%$ Confidence interval \\
a & Normally distributed & ANCOVA, post-test comparison & $0.97-1.47$ \\
b & Normally distributed & ANCOVA, post-test comparison & $0.54-0.93$ \\
c & Normally distributed & ANCOVA, post-test comparison & $0.15-0.60$ \\
d & Normally distributed & ANCOVA, type III test interaction & NA \\
e & Normally distributed & ANCOVA, type III test interaction & $0.14-0.24$ \\
f & Normally distributed & ANCOVA, post-test comparison & $0.16-0.22$ \\
g & Normally distributed & ANCOVA, post-test comparison & $0.12-1.10$ \\
h & Normally distributed & ANCOVA, post-test comparison & $0.13-0.61$ \\
i & Normally distributed & ANCOVA, post-test comparison & $0.38-0.90$ \\
j & Normally distributed & ANCOVA, post-test comparison & $0.04-0.18$ \\
k & Normally distributed & ANCOVA, post-test comparison & $0.14-0.32$ \\
l & Normally distributed & ANCOVA, post-test comparison & $0.27-0.35$ \\
m & Normally distributed & ANCOVA, post-test comparison & $0.05-0.19$ \\
$\mathrm{n}$ & Normally distributed & ANCOVA, post-test comparison & $0.04-0.20$ \\
o & Normally distributed & ANCOVA, post-test comparison & $0.65-0.79$ \\
p & Normally distributed & ANCOVA, post-test comparison & $0.63-1.09$ \\
q & Normally distributed & ANCOVA, post-test comparison & -0.03 to 0.33 \\
r & Normally distributed & ANCOVA, post-test comparison & $0.22-1.32$ \\
s & Normally distributed & ANCOVA, post-test comparison & $0.24-0.36$ \\
t & Normally distributed & ANCOVA, post-test comparison & $0.42-0.53$ \\
u & Normally distributed & ANCOVA, post-test comparison & $0.15-0.26$ \\
v & Normally distributed & ANCOVA, post-test comparison & $0.15-0.27$ \\
w & Normally distributed & ANCOVA, post-test comparison & \\
& & &
\end{tabular}

$\mathrm{ER} \alpha \mathrm{mRNA}$ and protein expression are unknown in the newborn hippocampus following $\mathrm{HI}$. To answer the question of whether $\mathrm{ER} \alpha$ plays a role in sex differences seen in neonatal brains post-HI, we quantified $\mathrm{ER} \alpha \mathrm{mRNA}$ and protein expression in hippocampi of both male and female neonate mice $3 \mathrm{~d}$ post-HI. Using qPCR and immunoblotting, we detected 3.1-fold greater ER $\alpha$ mRNA (Fig. 1A) and 2.4fold greater $\mathrm{ER} \alpha$ protein (Fig. $1 B$ ) expression in the IL hippocampus of female mice compared with male mice $3 \mathrm{~d}$ post-HI ( $p=0.001^{\mathrm{a}}$ and $p=0.0004^{\mathrm{b}}$, respectively) (Table 1). ER $\beta$ mRNA expression levels were below the limit of detection $\left(C_{t}\right.$ values $\left.>35\right)$ in both $C L$ and IL hippocampi obtained from sham-operated and post-HI mice in both sexes. The sexually differentiated up-regulation of $\mathrm{ER} \alpha$ prompted us to further investigate the role of $\mathrm{ER} \alpha$ in TrkB phosphorylation both in $\mathrm{ER} \alpha^{+/+}$and $\mathrm{ER} \alpha^{-/-}$mice.

\section{TrkB agonist therapy enhances $\mathrm{HI}$-induced hippocampal TrkB phosphorylation in neonatal females, but not in males}

Uluc et al. (2013) recently reported that 7,8-DHF triggers a significant sex-dependent neuroprotection in female neonatal mice hippocampi post-HI. However, the baseline and post-TrkB agonist treatment levels of $\mathrm{p}$-TrkB in sham-operated male and female neonatal mice were not assessed. To investigate the levels of hippocampal p-TrkB with and without 7,8-DHF therapy in shamoperated mice, we sham-operated P9 mice and determined levels of $\mathrm{p}-\mathrm{TrkB}^{\mathrm{Y} 705} 3 \mathrm{~d}$ after sham operation. We could not detect any sex differences in hippocampal TrkB $^{\mathrm{Y} 705}$ phosphorylation between treatment groups in sham-operated neonatal mice (Fig. $2 A-C$ ). Similar to the results of Uluc et al. (2013), we detected significantly higher hippocampal TrkB phosphorylation in 7,8-DHFtreated females compared with males at $3 \mathrm{~d}$ post-HI (1.34 \pm 0.18 vs $0.85 \pm 0.14, p=0.028^{c}$; Fig. $\left.2 B, C\right)$. A significant increase in hippocampal $\operatorname{TrkB}^{Y 705}$ phosphorylation in mice $3 \mathrm{~d}$ post-HI was also detected regardless of the sex and 7,8-DHF therapy $\left(p=0.0002^{d}\right)$. There was also a significant sex and $\mathrm{HI}$ interaction $\left(p=0.023^{\mathrm{e}}\right)$. This latter response is more robust in females than males and may account for the sexually differentiated neuroprotection observed with TrkB agonist therapy. We then sought to determine whether hippocampal $\mathrm{ER} \alpha$ expression is required for $\mathrm{TrkB}^{\mathrm{Y} 705}$ phosphorylation in neonatal mice post-HI or not, using $\mathrm{ER} \alpha^{-/-}$mice.

\section{$\mathrm{HI}$ and TrkB agonist therapy fails to increase the TrkB $^{\mathrm{Y} 515}$ phosphorylation in ER $\alpha^{-/-}$mice hippocampus}

To determine the role of $\mathrm{ER} \alpha$ in TrkB phosphorylation, we initially compared the hippocampal p-TrkB ${ }^{\text {Y515 }}$ expressions in both $\mathrm{ER} \alpha^{+/+}$and $\mathrm{ER} \alpha^{-/-}$mice post-HI by immunostaining. Supporting our in vivo immunoblotting studies, semiquantitative analysis of pTrkB immunostaining revealed an $\sim 17 \%$ increase in the $\mathrm{IL}$ hippocampal pTrkB $^{\mathrm{Y} 515}$ immunoreactivity at $3 \mathrm{~d}$ post-HI in the hippocampus of both male and female $\mathrm{ER} \alpha^{+/+}$mice (Fig. $3 A, B)$. The majority of the TrkB phosphorylation detected by immunostaining was in the dentate gyrus (Fig. $3 A$ ). In contrast, $\mathrm{p}$-TrkB ${ }^{\mathrm{Y5} 15}$ immunostaining was significantly less throughout the hippocampus, including the dentate gyrus in both male $\left(p=0.00004^{f}\right)$ and female $(p=$ $\left.0.00015^{9}\right) \mathrm{ER}^{-1-}$ mice compared with $\mathrm{ER} \alpha^{+/+}$mice (Fig. $3 A, B)$. This suggests that $\mathrm{ER} \alpha$ is required for the $\mathrm{HI}$ induced increase in hippocampal p-TrkB post-HI.

To confirm our immunostaining findings, immunoblotting experiments were performed to quantify the hippocampal $\mathrm{p}-\mathrm{TrkB}^{\mathrm{Y} 705} / \mathrm{f}-\mathrm{TrkB}$ ratio in $\mathrm{ER} \alpha^{-/-}$male and female mice post-HI (Fig. 4). Neither $\mathrm{HI}$ nor 7,8-DHF 

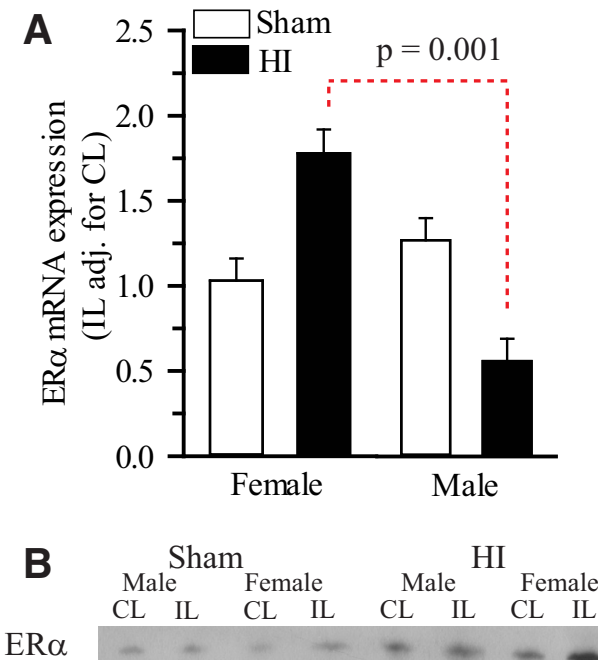

$\beta$-actin

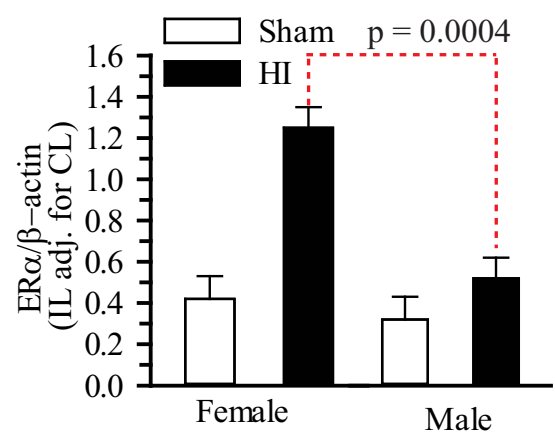

Figure 1. ER $\alpha$ mRNA and protein expressions in hippocampus at $3 \mathrm{~d}$ post-HI. ER $\alpha^{+/+}$mice were subjected to either sham operation or HI. Three days, later the male and female hippocampi were probed for the quantification of $\mathrm{ER} \alpha \mathrm{mRNA}$ and $\mathrm{ER} \alpha$ protein expressions. A, Hippocampal ER $\alpha$ mRNA expression was quantified $3 \mathrm{~d}$ post-HI using qPCR. Data is IL expression relative to sham-operated female, adjusted for $\mathrm{CL} \pm$ SEM, $n=5-6$. $n=$ number of pups. $\boldsymbol{B}$, Top, Representative blot of ER $\alpha$ protein expression in the IL and CL neonatal hippocampi from male and female mice subjected to either sham operation or HI. Blot was probed for $\beta$-actin as a loading control. Bottom, Summary figure of the $\mathrm{ER} \alpha / \beta$-actin ratio in male and female hippocampi of sham and $\mathrm{HI}$ mice. Data are mean IL adjusted for CL \pm SEM, $n=3-4 . n=$ number of blots per group (2 pups per group).

therapy increased the hippocampal TrkB phosphorylation in the $\mathrm{ER} \alpha^{-1-}$ mice (Fig. 4). Interestingly, the sexually differentiated hippocampal TrkB phosphorylation observed in female $\mathrm{ER}^{+/+}$mice was also abolished in $\mathrm{ER} \alpha^{-/-}$mice. Together, these data suggest that there is preferential TrkB phosphorylation in female neonates that depends on the $\mathrm{ER} \alpha$ activity.

\section{Enhanced 7,8-DHF-dependent hippocampal TrkB phosphorylation in females does not depend on expression of TrkB isoforms}

TrkB can exist in other isoforms that could affect its signaling capacity. The two dominant TrkB receptor iso-
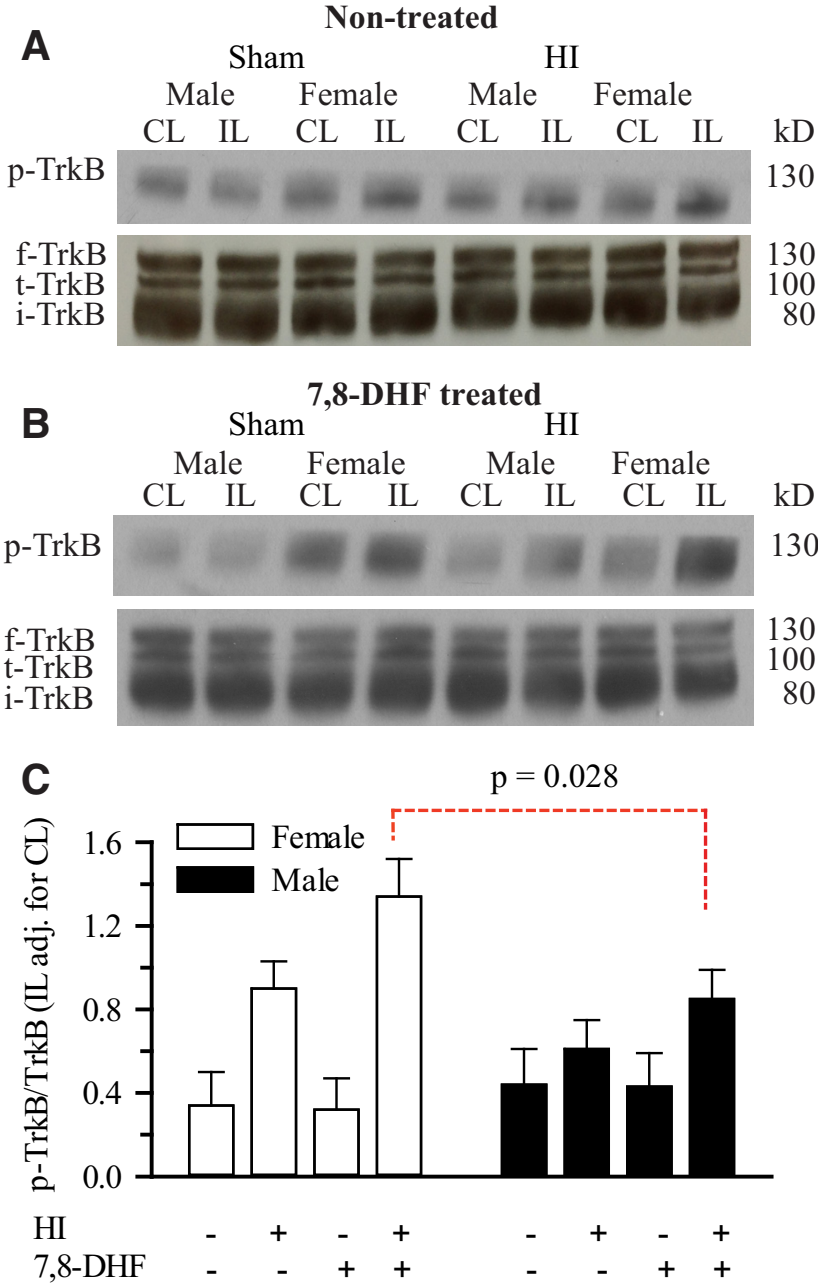

Figure 2. Effect of $\mathrm{HI}$ and 7,8-DHF on hippocampal TrkB phosphorylation in ER $\boldsymbol{\alpha}^{+/+}$mice. ER $\alpha^{+/+}$mice were subjected to either sham operation or $\mathrm{HI}$, with or without $7,8-\mathrm{DHF}$ treatment. Three days later, the male and female hippocampi from the $\mathrm{CL}$ and IL sides were probed for phosphorylated TrkB ( $p$ TrkB) expression, full-length TrkB (f-TrkB), truncated TrkB ( $t-$ TrkB), immature TrkB (i-TrkB), or degraded TrkB (d-TrkB). $\boldsymbol{A}$, Representative blots of $p$-TrkB, and f-TrkB, t-TrkB, i-TrkB in the neonatal hippocampi of sham and $\mathrm{HIER} \alpha^{+/+}$mice without 7,8-DHF treatment. $\boldsymbol{B}$, Representative blots of $p$-TrkB, and $\mathrm{f}$-TrkB, t-TrkB, i-TrkB in the neonatal hippocampi of sham and $\mathrm{HI}$ $\mathrm{ER} \alpha^{+/+}$mice with 7,8-DHF treatment. $\boldsymbol{C}$, Summary figure of the $\mathrm{p}$-TrkB/f-TrkB ratio in female and male hippocampi of sham and $\mathrm{HI} \mathrm{ER} \alpha^{+/+}$mice with and without 7,8-DHF treatment. Data are mean IL adjusted for CL \pm SEM, $n=3-4 . n=$ number of blots per group (2 pups per group).

forms expressed in the brain are full-length ( $f$-TrkB) and truncated TrkB (t-TrkB). Presence of $t-T r k B$ can prevent $f-T r k B$ phosphorylation in male mouse mammary gland (Liu et al., 2012). In addition, Golder et al. proposed that intermittent hypoxia can result in the synthesis of an immature form of TrkB (i-TrkB) which is hypoglycosylated and when phosphorylated results in ligand-independent TrkB signaling (Golder et al., 2008). Therefore, we determined the levels of $f-T r k B, t-T r k B$, and i-TrkB in the hip- 
A
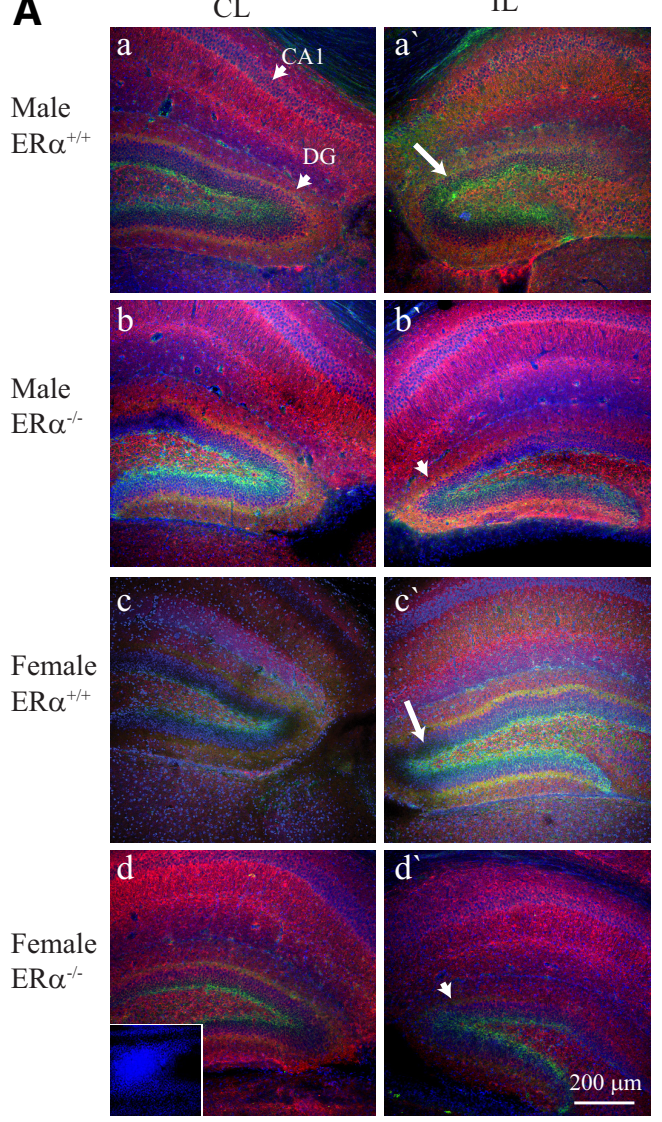

B

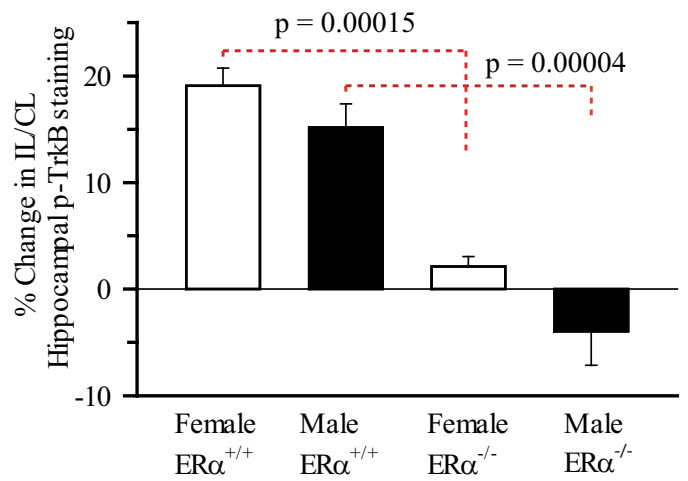

Figure 3. Immunohistological staining of $\mathrm{p}-\mathrm{TrkB}^{\mathrm{Y} 515}$ in $E R \alpha^{+/+}$and ER $\boldsymbol{\alpha}^{-/-}$mice 3 d post- HI. A, Changes in MAP2 and $\mathrm{p}-\mathrm{TrkB}^{\mathrm{Y} 515}$ immunoexpression in the $\mathrm{CL}$ and IL hippocampi of $\mathrm{ER} \alpha^{+/+}$and $\mathrm{ER} \alpha^{-/-} \mathrm{P} 9$ male and female mice were examined $3 \mathrm{~d}$ post-HI. MAP2 (red), p-TrkB ${ }^{\mathrm{Y} 515}$ (green), and DAPI (blue). Arrow, Increased $\mathrm{p}-\mathrm{TrkB}^{\mathrm{Y} 515}$ staining. Arrowhead, Decreased $\mathrm{p}$-TrkB ${ }^{\mathrm{Y} 515}$ in $\mathrm{ER} \alpha^{-1-}$ hippocampi. Inset, Primary antibody control. Scale bar, $200 \mu \mathrm{m}$. B, Summary figure showing the percent change in IL/CL ratio of hippocampal mean $\mathrm{p}$-TrkB ${ }^{\mathrm{Y} 515}$ fluorescent intensities in $\mathrm{ER} \alpha^{+/+}$and $\mathrm{ER} \alpha^{-/-}$male and female mice hippocampi $3 \mathrm{~d}$ post-HI. IL/CL ratio of $\mathrm{p}-\mathrm{TrkB}^{\mathrm{Y} 515}$ obtained from uninjured naïve mouse hippocampus was assumed to be one. Three hippocampal slices per brain were analyzed. Data are mean \pm SEM. $n=8$ for ER $\alpha^{+/+}$and $n=3$ for $\mathrm{ER} \alpha^{-/-}$. $n=$ number of pups.

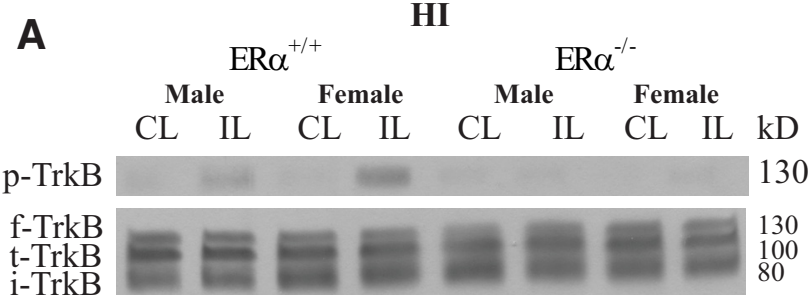

B

\section{$\mathrm{HI}+$ 7,8-DHF treated}
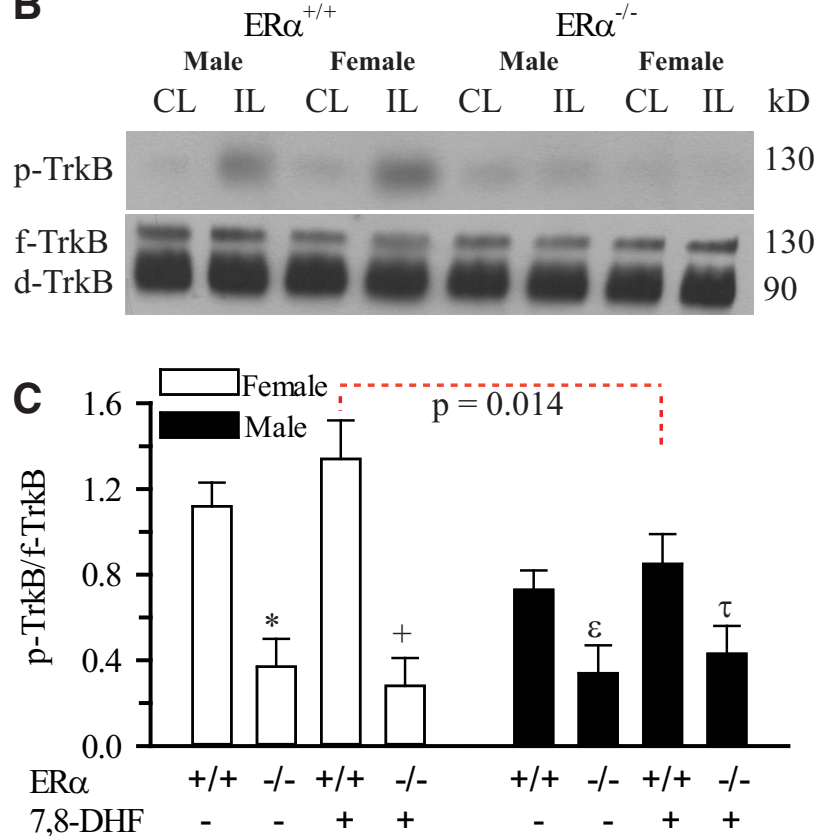

Figure 4. Effect of $\mathrm{HI}$ and 7,8-DHF on hippocampal p-TrkB in $\mathbf{E R} \boldsymbol{\alpha}^{+/+}$and $\mathbf{E R} \boldsymbol{\alpha}^{-/-}$mice. $\mathrm{ER} \alpha^{+/+}$and $\mathrm{ER} \alpha^{-/-}$mice were subjected to $\mathrm{HI}$ with and without 7,8-DHF therapy. Three days later, the male and female hippocampi from the CL and IL sides were probed for $\mathrm{p}-\mathrm{TrkB}^{\mathrm{Y} 705}$ expression, f-TrkB, t-TrkB, and i-TrkB. A, Representative blots of hippocampal p-TrkB (top), $\mathrm{f}$-TrkB, t-TrkB and i-TrkB in $\mathrm{ER} \alpha^{+/+}$and $\mathrm{ER} \alpha^{-/-}$mice without 7,8-DHF therapy $3 \mathrm{~d}$ post-HI. $\boldsymbol{B}$, Representative blots of hippocampal p-TrkB (top), f-TrkB, d-TrkB (t-TrkB and i-TrkB) in $\mathrm{ER} \alpha^{+/+}$and $\mathrm{ER} \alpha^{-/-}$mice with 7,8-DHF therapy $3 \mathrm{~d}$ post-HI. $\mathbf{C}$, Summary figure of the hippocampal $p$-TrkB/f-TrkB ratio in $\mathrm{ER} \alpha^{+/+}$and $\mathrm{ER} \alpha^{-/-}$mice with and without 7,8-DHF therapy $3 \mathrm{~d}$ post-HI. Data are mean IL adjusted for CL \pm SEM, $n=3$. $n=$ number blots per group. $* p=0.018^{p},+p=0.035^{q}, \varepsilon p=0.334^{r}$, $\tau p=0.0488^{\text {s }}$ versus $\mathrm{ER} \alpha^{+/+}$.

pocampi in sham and $\mathrm{HI}$ mice with and without 7,8-DHF therapy. As seen in Figure 5, under sham and $\mathrm{HI}$ conditions, we detected no difference in $\mathrm{f}$-TrkB and $\mathrm{i}$-TrkB levels between male and female hippocampi with and without 7,8-DHF therapy. There was a trend towards higher f-TrkB levels in female compared with male hippocampi $3 \mathrm{~d}$ post-HI without the 7,8-DHF therapy, but did not reach statistical significance $(p=0.08)$. There was a statistically significant difference in $\mathrm{f}$-TrkB levels between the female sham and $\mathrm{HI}$ animals, this difference did not persist in 7,8-DHF treated animals $\left(p=0.01^{\mathrm{h}}\right)$. However, our results did show a statistically higher hippocampal 

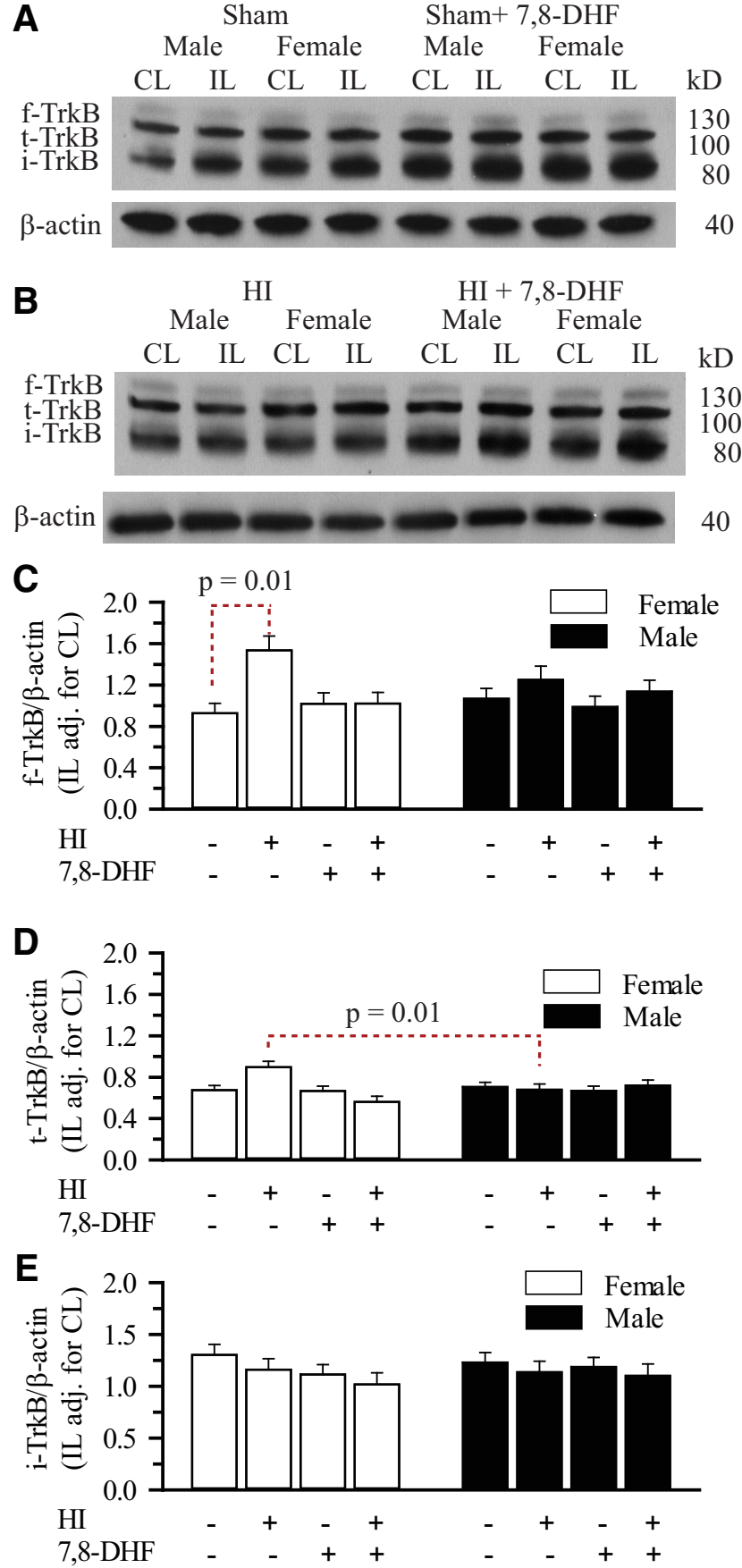

Figure 5. Effect of $\mathrm{HI}$ and 7,8-DHF on hippocampal TrkB subtypes in ER $\boldsymbol{\alpha}^{+/+}$mice. The hippocampi of male and female $\mathrm{ER} \alpha^{+/+}$mice were probed for full-length TrkB (f-TrkB), truncated TrkB (t-TrkB), immature TrkB (i-TrkB), and $\beta$-actin. $\boldsymbol{A}$, Representative blots of $\mathrm{f}$-TrkB, t-TrkB, i-TrkB, and $\beta$-actin from shamoperated male and female neonatal hippocampi with and without 7,8-DHF therapy. $\boldsymbol{B}$, Representative blots of $f-T r k B, t-T r k B$, $\mathrm{i}$-TrkB and $\beta$-actin from male and female neonatal hippocampi with and without 7,8-DHF therapy $3 \mathrm{~d}$ post-HI. C, Summary figure of the $\mathrm{f}-\mathrm{TrkB} / \beta$-actin ratio in male and female hippocampi with and without 7,8-DHF therapy $3 \mathrm{~d}$ post-sham operation or post-HI. Data are mean \pm SEM, $n=3-4$. $n=$ number of blots per group. $\boldsymbol{D}$, Summary figure of the $\mathrm{t}-\mathrm{TrkB} / \beta$-actin ratio in male and female hippocampi with and without 7,8-DHF therapy $3 \mathrm{~d}$ postsham operation or post-HI. Data are mean \pm SEM, $n=3-4$.
Figure 5. continued

$n=$ number of blots per group. $\boldsymbol{E}$, Summary figure of the i-TrkB/ $\beta$-actin ratio in male and female hippocampi with and without 7,8-DHF therapy $3 \mathrm{~d}$ post-sham surgery or post-HI. Data are mean IL adjusted for CL \pm SEM, $n=3-4 . n=$ number of blots per group.

t-TrkB expression in female IL hippocampus (adjusted for $\mathrm{CL})$ post-HI compared with males $\left(p=0.01^{i}\right)$, this significance did not hold in 7,8-DHF treated females post-HI. More importantly, there was no difference in hippocampal t-TrkB expression between males and females with 7,8DHF therapy at $3 \mathrm{~d}$ post-HI. Thus, the sexually differentiated hippocampal TrkB $^{\mathrm{Y} 705}$ phosphorylation in response to 7,8-DHF therapy does not appear to be dependent on differential expression of TrkB subtypes post-HI.

\section{BDNF mRNA expression is decreased in female hippocampus $3 \mathrm{~d}$ post-HI}

Given that $\mathrm{ER} \alpha$ mRNA and protein expression are increased in the female hippocampus post-HI and that genetic ablation of $\mathrm{ER} \alpha$ abolishes $\mathrm{HI}$-induced TrkB phosphorylation in both males and females, we investigated the possible mechanisms linking $\mathrm{ER} \alpha$ and TrkB. One possibility would be through the classical ER $\alpha$ signaling pathway. This involves $\mathrm{E}_{2}$ binding to nuclear $\mathrm{ER} \alpha$ resulting in DNA binding at estrogen response elements in the BDNF promoter region resulting in differentially increased BDNF expression in females. However, in our experiments BDNF mRNA expression was not increased, but instead significantly decreased in female hippocampus at $3 \mathrm{~d}$ post-HI ( $p=0.003^{\mathrm{j}}$; Fig. 6). Given that the classical ER $\alpha$ pathway may not account for the crosstalk between the hippocampal ER $\alpha$ and TrkB, we then investigated nonclassical ER $\alpha$ signaling which can involve rapid nongenomic signaling via membrane localized extranuclear $\mathrm{ER} \alpha$ that is linked to rapid activation of signal-regulated kinases.

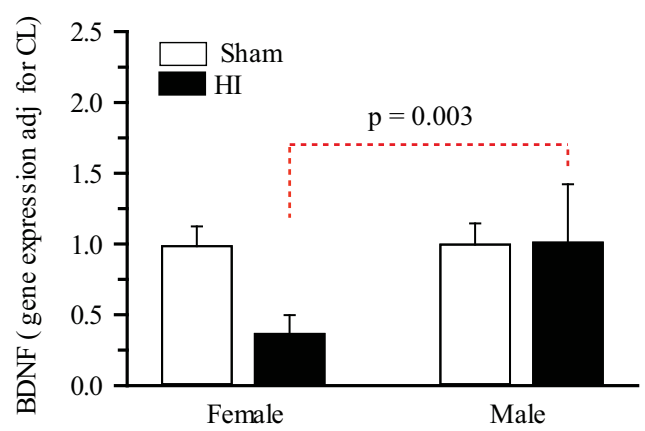

Figure 6. BDNF gene expression are sexually differentiated in P9 neonatal hippocampi 3 d post-HI. BDNF mRNA expression was quantified with qPCR in the hippocampi of male and female mice $3 \mathrm{~d}$ after sham operation or $\mathrm{HI}$ in $\mathrm{ER} \alpha^{+/+}$mice. Data is mean IL expression relative to sham female, adjusted for $\mathrm{CL} \pm$ SEM, $n=5-6$. $n=$ number of pups. 


\section{Sexually differentiated expression of $\mathrm{p}$-src $\mathrm{S}^{\mathrm{Y} 18}$ in neonatal hippocampus is ER $\alpha$ dependent}

Recent evidence suggests that there is a complex interplay of $\mathrm{ER} \alpha$ with nerve growth factor receptor signaling that in part involves activation of the cellular tyrosine kinases called SFKs (Arpino et al., 2008). In this study, we proposed that activation of src, represents one of the initial steps in ER $\alpha$-mediated cell signaling and that activation of SFK regulates TrkB in part by direct phosphorylation of TrkB at Y705/Y706 (Barletta et al., 2004; Huang and McNamara, 2010). Therefore, we determined the $\mathrm{p}$-src ${ }^{\mathrm{Y} 418}$ expression in neonatal hippocampus $3 \mathrm{~d}$ post-HI as a surrogate marker for the SFK activity.

Our results show a small increase in the $\mathrm{p}-\mathrm{src}^{\mathrm{Y} 418} \mathrm{im}$ munostaining in IL hippocampus of the male $\mathrm{ER} \alpha^{+/+}$mice $3 \mathrm{~d}$ post-HI (Fig. 7A, top row, left). By contrast, a robust increase in the $\mathrm{p}$-src ${ }^{\mathrm{Y}}{ }^{18}$ staining in the IL hippocampus of the female $\mathrm{ER}^{+/+}{ }^{+1}$ mice occurred (Fig. $7 A$, top row, right). In the absence of $\mathrm{ER} \alpha$, this sex difference in $\mathrm{HI}$-induced p-src ${ }^{\Upsilon 418}$ expression was abolished (Fig. 7A, bottom row). To confirm these immunostaining findings, we detected $\mathrm{p}$-src ${ }^{\mathrm{Y} 418}$ protein expression using immunoblotting (Fig. $7 B-D$ ). Immunoblotting results also showed that $\mathrm{p}-\mathrm{src}^{\mathrm{Y} 418}$ protein expressions were significantly higher $(1.5$-fold $)$ in female IL hippocampus post-HI $\left(p=0.045^{j}\right)$ and $(1.6$-fold) after 7,8-DHF therapy $\left(p=0.001^{\prime}\right)$ compared with males post-HI (Fig. 7E). The sex differences seen in $\mathrm{p}$-src ${ }^{\mathrm{Y} 418}$ with and without TrkB agonist therapy were abolished in $\mathrm{ER} \alpha^{-1-}$ mice $\left(p<0.0001^{\mathrm{m}}\right.$; Fig. 7F) post-HI. We detected no statistically significant differences between the sexes in $\mathrm{p}$-src ${ }^{\mathrm{Y} 118}$ expression in sham mice with or without 7,8-DHF therapy. These results reveal that phosphorylation of $\operatorname{src}^{\mathrm{Y} 418}$ is dependent on $\mathrm{ER} \alpha$ and thus could mediate the $\mathrm{ER} \alpha$-TrkB crosstalk in neonatal mice hippocampus post-HI.

\section{Genetic ablation of ER $\alpha$ increases apoptosis in female hippocampus post-HI}

TrkB signaling leads to activation of prosurvival pathways including PI3K/AKT, PLC $\gamma-\mathrm{Ca}^{2+}$, and Ras/MAPK (Minichiello, 2009). Thus, the enhanced responsiveness to the TrkB agonist therapy that we observe in female hippocampus would be expected to reduce post-HI apoptosis in these mice. Conversely, c-caspase- 3 expression in mice in which $\mathrm{ER} \alpha$ has been genetically ablated should be increased post-HI. To confirm this hypothesis, we investigated c-caspase-3 expression in the hippocampus of $\mathrm{ER} \alpha^{+/+}$and $\mathrm{ER} \alpha^{-/-}$mice with and without 7,8-DHF therapy at $1 \mathrm{~d}$ post-HI. As seen in Figure $8 A$, left, c-caspase-3 immunostaining was increased at $1 \mathrm{~d}$ post- $\mathrm{HI}$ in the female $\mathrm{ER} \alpha^{+/+}$mouse hippocampus. Interestingly, genetic ablation of $\mathrm{ER} \alpha$ resulted in a marked increase in C-caspase-3 immunostaining in the IL female hippocampus (Fig. $8 A$, right). This suggests that $\mathrm{ER} \alpha$ inhibits apoptosis in female neonatal hippocampus and contributes to neuroprotection post- HI. To further confirm these results, we quantified the c-caspase- 3 protein expression in male and female hippocampus from $\mathrm{ER} \alpha^{+/+}$and $\mathrm{ER} \alpha^{-/-}$mice (Fig. $8 B-D)$ at $1 \mathrm{~d}$ post-HI. We detected significantly higher $\mathrm{c}$-caspase- 3 expression in the hippocampus of
$\mathrm{ER} \alpha^{+/+}$male mice compared with $\mathrm{ER} \alpha^{+/+}$female mice $\left(p=0.047^{\mathrm{n}}\right)$. In addition, TrkB agonist therapy mediated attenuation of $c$-caspase- 3 levels observed in female $\mathrm{ER} \alpha^{+/+}$mice is abolished in the absence of $\operatorname{ER} \alpha(p=$ $0.043^{\circ}$ ). Together, our data suggest that the sexually differentiated response to $\mathrm{HI}$ and $\mathrm{HI}+\mathrm{p}$-TrkB agonist therapy in the female neonate hippocampus is mediated by $\mathrm{ER} \alpha$ and provides neuroprotection via facilitation of prosurvival cell signaling pathways downstream of TrkB phosphorylation. However, there were no differences detected in attenuation or exacerbation of the apoptosis when assessed by c-caspase- 3 levels in male neonate hippocampus regardless of the TrkB agonist therapy or $\mathrm{ER} \alpha$ status $1 \mathrm{~d}$ post-HI.

\section{Discussion}

In this study, we tested the hypothesis that $\mathrm{HI}$ preferentially induces ER $\alpha$ expression in female neonatal hippocampus and that $E R \alpha$ is coupled to SFK activation that in turn augments phosphorylation of the TrkB and thereby results in decreased apoptosis and neuronal injury. Our studies confirm the validity of four key elements of this hypothesis, namely that: (1) $\mathrm{HI}$ differentially induces $\mathrm{ER} \alpha$ expression in the hippocampus of the female versus male neonate, (2) src and TrkB phosphorylation post-HI is greater in females than in males after 7,8-DHF therapy, (3) src and TrkB phosphorylation post-HI depend upon the presence of $\mathrm{ER} \alpha$, (4) TrkB agonist therapy decreases the C-caspase-3 only in $\mathrm{ER} \alpha^{+/+}$female mice hippocampus (Fig. 9). These observations provide evidence that femalespecific induction of ER $\alpha$ expression post-HI confers enhanced SFK activation, and thus enhanced neurotrophin signaling and neuroprotection with TrkB agonist therapy that may account for improved functional outcomes in female neonates following $\mathrm{HI}$.

\section{Neuroprotective role of ER $\alpha$ post-HI}

Using $\mathrm{ER} \alpha$ and $\mathrm{ER} \beta$ KO mice Dubal et al. (2001) demonstrated that the neuroprotective effects of $E_{2}$ in adult rodents were dependent on $\mathrm{ER} \alpha$ but not on ER $\beta$ after MCAO. It has also been reported that $\mathrm{ER} \alpha$ is differentially increased in adult female cortex compared with males at the ischemia site after MCAO (Westberry et al., 2010). Although it has been shown that $\mathrm{ER} \alpha$ is equally expressed in both naïve male and female neonatal rat hippocampus (Miranda et al., 1994;Solum and Handa, 2002; Pérez et al., 2003), the involvement of $\mathrm{ER} \alpha$ in the neuroprotective effects of $E_{2}$ in neonatal brains have not been studied. We report here that $\mathrm{ER} \alpha$ expression is upregulated in the ischemic neonatal hippocampus in a sexually differentiated manner, with greater $\mathrm{ER} \alpha \mathrm{mRNA}$ and protein expression occurring in the female versus male neonate, in a manner similar to that previously reported in adult rodents at the ischemia site after MCAO (Westberry et al., 2010). The mechanisms that mediate this differential induction of $\mathrm{ER} \alpha \mathrm{mRNA}$ expression are unknown. One possibility is the epigenetic regulation of the $\mathrm{ER} \alpha$ promoter region as it has been shown that the increase in expression of ER $\alpha$ mRNA in the adult female cerebral cortex following MCAO is due to demethylation of the $\mathrm{ER} \alpha$ promoter in response to brain injury (Westberry et al., 2008). In adult males, 
A

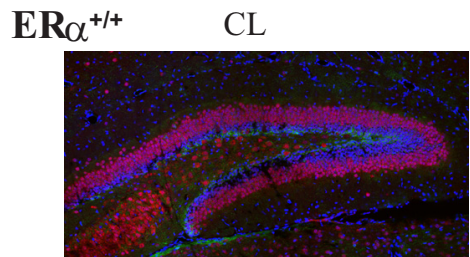

$\mathbf{E R} \alpha^{-1-}$

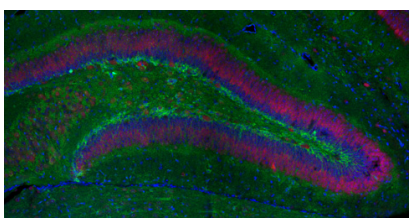

Male

IL
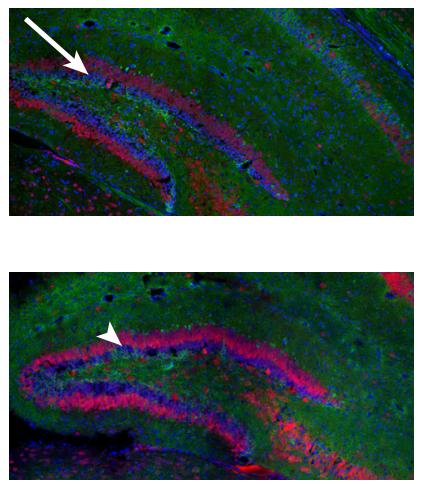

Female

CL
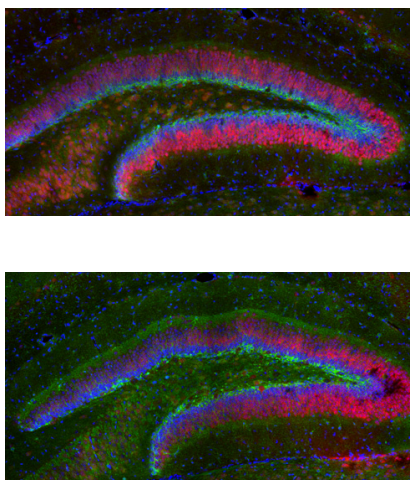

IL
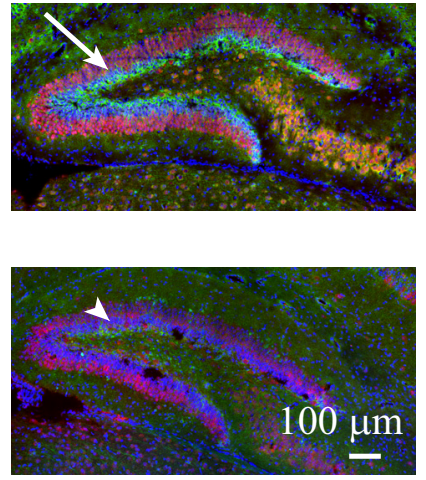

B

Sham

Sham + 7,8-DHF

$$
\mathrm{ER} \alpha^{-1-}
$$

Male Female Male Female

$\mathrm{CL}$ IL CL IL CL IL CL IL kD

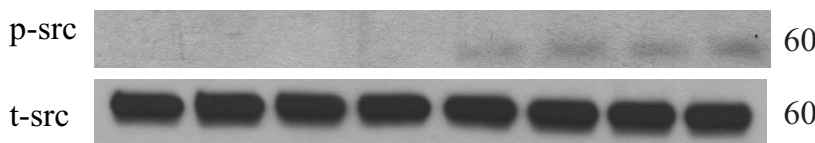

\section{HI}

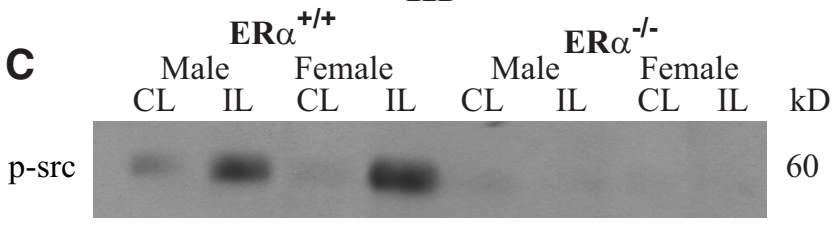

t-src

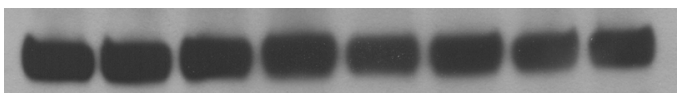

60
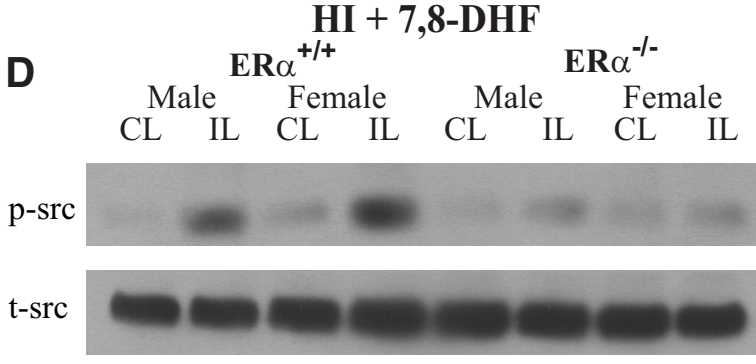

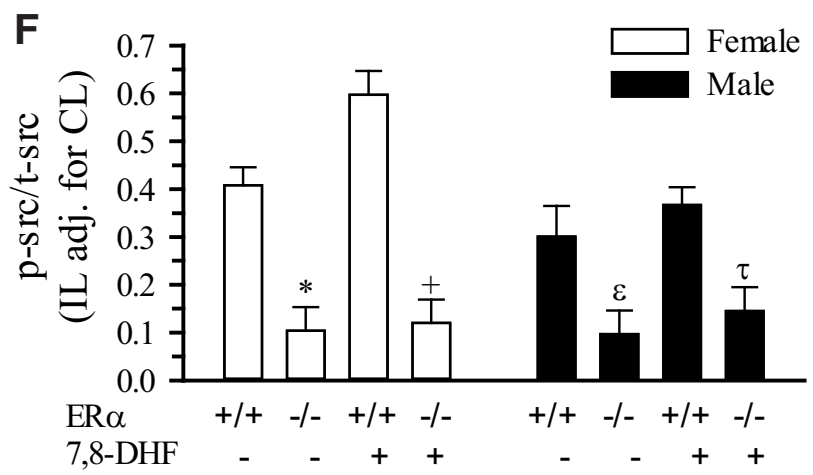

Figure 7. Hippocampal p-src ${ }^{\mathrm{Y} 418}$ is sexually differentiated and ER $\alpha$-dependent post-HI. $\boldsymbol{A}$, Changes in the NeuN (red) and p-src ${ }^{\mathrm{Y} 418}$ (green) immunoexpression in the $\mathrm{CL}$ and IL dentate gyrus of $\mathrm{ER} \alpha^{+/+}$and $\mathrm{ER} \alpha^{-/-} \mathrm{P9}$ mice examined at $3 \mathrm{~d}$ post-HI. Left two columns $=$ male; right two columns $=$ female; top row $=\mathrm{ERR} \alpha^{+/+}$; bottom row $=\mathrm{ER} \alpha^{-/-}$. Arrow, Increased $p$-src ${ }^{\Upsilon 418}$ staining. Arrowhead, Unchanged or decrease $\mathrm{p}$-src ${ }^{\mathrm{Y} 18}$ in IL hippocampi. Scale bar, $200 \mu \mathrm{m} \boldsymbol{B}$, Representative blots of $\mathrm{p}$-src $\mathrm{S}^{\mathrm{Y} 18}$ and t-src from $\mathrm{ER} \alpha^{+/+}$male and female neonatal hippocampi. Mice were subjected to sham operation with and without 7,8-DHF therapy and the brains harvested $3 \mathrm{~d}$ later. C, Representative blots of $\mathrm{p}-\mathrm{src}^{\mathrm{Y} 418}$ and $\mathrm{t}$-src from $\mathrm{ER} \alpha^{+/+}$and $\mathrm{ER} \alpha^{-/-}$male and female neonatal hippocampi. Mice were subjected to $\mathrm{HI}$ and the brains harvested $3 \mathrm{~d}$ later. $\boldsymbol{D}$. Representative blots of $\mathrm{p}-\mathrm{src}^{\mathrm{Y} 418}$ and $\mathrm{t}$-src from $\mathrm{ER} \alpha^{+/+}$and $\mathrm{ER} \alpha^{-/-}$male and female neonatal hippocampi. Mice were subjected to HI with 7,8-DHF therapy and the brains harvested $3 \mathrm{~d}$ later. E, Summary figure of the IL p-src ${ }^{\mathrm{Y} 418} / \mathrm{t}-\mathrm{src}$ ratio adjusted for $\mathrm{CL}$ in male and female hippocampi $3 \mathrm{~d}$ post-sham operation or post- $\mathrm{HI}$ with and without 7,8-DHF therapy. Data are mean IL adjusted for $\mathrm{CL} \pm \mathrm{SEM}, n=3-5 . n=$ number of blots per group (2 hippocampi per group). $\boldsymbol{F}$, Summary figure of the $\mathrm{p}$-src $\mathrm{s}^{\mathrm{Y} 18} / \mathrm{t}$-src ratio in $\mathrm{ER} \alpha^{+/+}$and $\mathrm{ER} \alpha^{-/-}$, male and female hippocampi $3 \mathrm{~d}$ post- HI with and without 7,8-DHF therapy. Data are mean IL adjusted for CL \pm SEM, $n=3-5 . n=$ number of blots per group. $* p=0.002^{\mathrm{t}},+p=0.001^{\mathrm{u}}, \varepsilon p=0.006^{\mathrm{v}}, \tau p=0.007^{\mathrm{w}}$ versus $\mathrm{ER} \alpha^{+/+}$. 
A

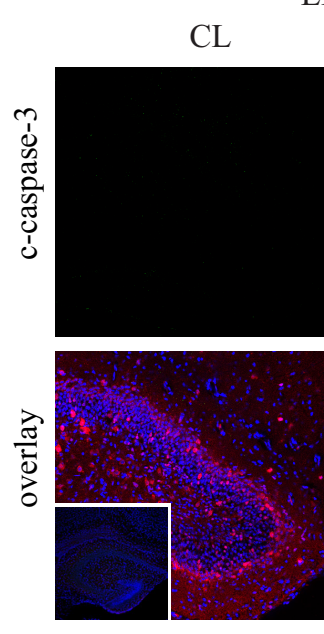

$\mathrm{ER}^{+/ /+}-\mathrm{HI}$
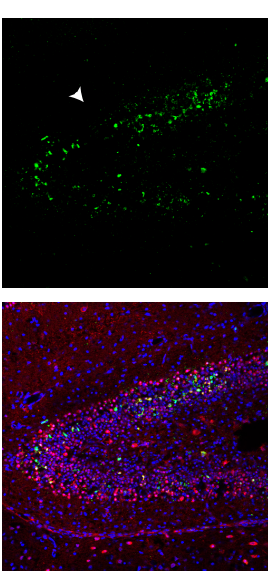

Female Dentate Gyrus

$$
\begin{aligned}
& \mathrm{ER}^{+/+}-\mathrm{HI} \\
& +7,8-\mathrm{DHF}
\end{aligned}
$$

CL
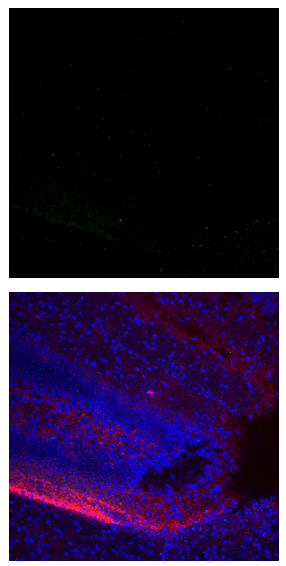

IL
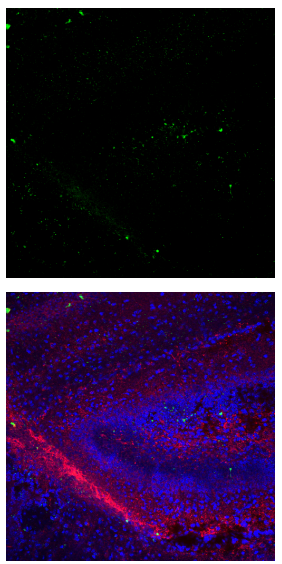

$\mathrm{ER}^{-/-}-\mathrm{HI}$

CL
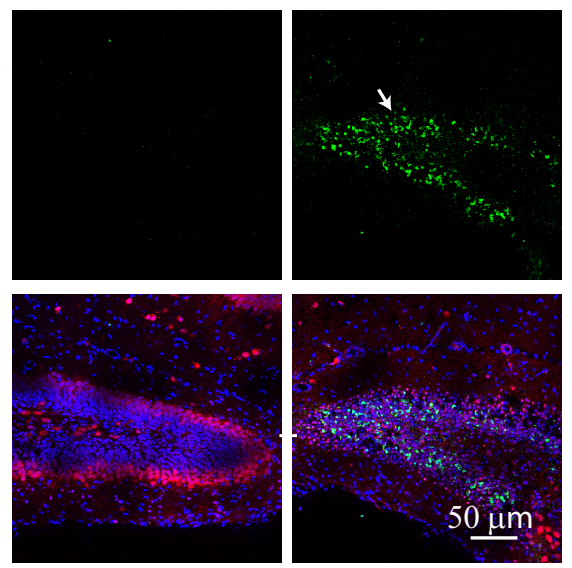

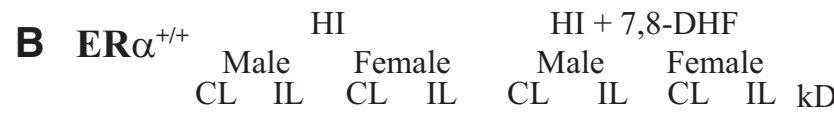

c-caspase 3

$\beta$-actin
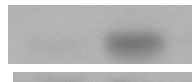

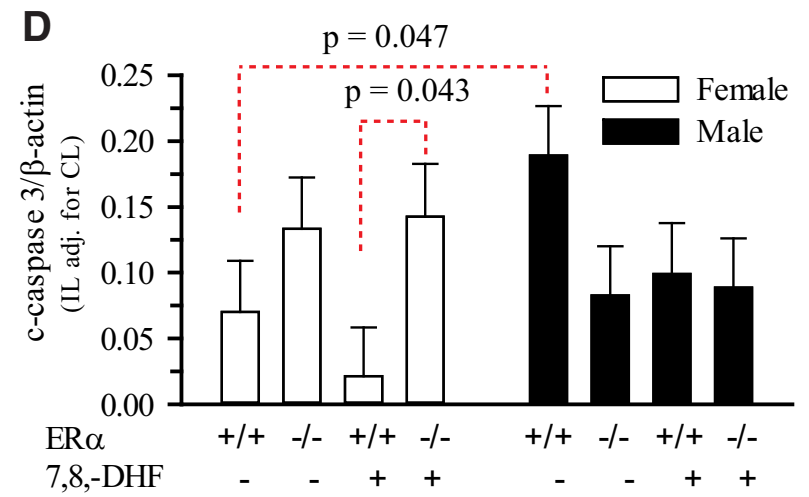

$\mathrm{HI}+7,8-\mathrm{DHF}$

Male Female CL IL CL IL kD 17 40
7,8,-DHF

Figure 8. TrkB agonist treatment decreases hippocampal apoptosis in $\mathrm{ER} \alpha^{+/+}$female mice but has no effect in ER $\alpha^{-/-}$female mice. $\boldsymbol{A}$, Brain slices from female P9 mice were stained for c-caspase-3 (green), NeuN (red), and DAPI (blue) at $24 \mathrm{~h}$ post-HI. Left two columns $=$ female $\mathrm{ER} \alpha^{+/+} ;$middle two columns $=$female $\mathrm{ER} \alpha^{+/+}$with 7,8-DHF therapy; left two columns $=$female $\mathrm{ER} \alpha^{-/-}$. Arrow head, Increased c-caspase-3 staining in ER $\alpha^{+/+}$IL dentate gyrus. Arrow, Augmented levels of c-caspase-3 staining in ER $\alpha^{-1-}$ IL dentate gyrus. Inset, Antibody control. Scale bar, $50 \mu \mathrm{m}$. B, C, Representative blots of C-caspase-3 in male and female neonatal hippocampi from $\mathrm{ER} \alpha^{+/+}$and $\mathrm{ER} \alpha^{-/-}$with and without 7,8-DHF therapy $24 \mathrm{~h}$ post-HI. Blots were probed for $\beta$-actin as a loading control. $\boldsymbol{D}$, Summary figure of the IL c-caspase-3/ $\beta$-actin ratio corrected for $\mathrm{CL}$ in $\mathrm{ER} \alpha^{+/+}$and $\mathrm{ER} \alpha^{-/-}$male and female hippocampi with and without 7,8-DHF therapy. Data are mean IL corrected for $\mathrm{CL} \pm \mathrm{SEM}, n=3, n=$ number of blots per group (2 hippocampi per group).

there was no change in the methylation status of the $\mathrm{ER} \alpha$ promoter which might explain the lack of increase in $\mathrm{ER} \alpha$ mRNA in the cortex of male rats following MCAO.

\section{TrkB phosphorylation is more robust in the female neonate hippocampus post-HI}

We have examined the possibility that the $\mathrm{ER} \alpha$ expression is linked to decreased neurodegeneration and improved neurological outcome via interactions of $\mathrm{ER} \alpha$ with TrkB signaling. Neurotrophins, such as BDNF, play critical roles in neuronal survival, neurogenesis, and synaptic plasticity (Waterhouse et al., 2012; Bothwell, 2014). Intracerebroventricular administration of BDNF produces rapid and robust increase in $\mathrm{p}$-TrkB in the hippocampus and provides dramatic reduction in tissue loss $7 \mathrm{~d}$ post- $\mathrm{HI}$ in P7 rats. Similarly, BDNF pre-therapy in P7 rats results in improved spatial memory deficits and reduced caspase-3 activation at $30 \mathrm{~d}$ or $24 \mathrm{~h}$ post-HI, respectively (Almli et al., 2000; Han et al., 2000). However, the poor bioavailability of BDNF to the brain limits its therapeutic value (Poduslo and Curran, 1996) and small pharmacologic molecules were developed to activate TrkB exogenously such as 7,8-DHF (Jang et al., 2010), LM22A-4 (Han et al., 2012), adenosine A2A receptor agonists (Zeng et al., 2013), and TrkB-selective antibodies (Cazorla et al., 2011). Thus, pre-therapy with 7,8-DHF reduces stroke volume in adult male mice $2 \mathrm{~d}$ after MCAO (Jang et al., 2010) and reverses memory deficits in a mouse model of Alzheimer's disease (Devi and Ohno, 2012). Similarly, the small molecule BNDF ligand LM22A improves functional outcomes in 
Hippocampus

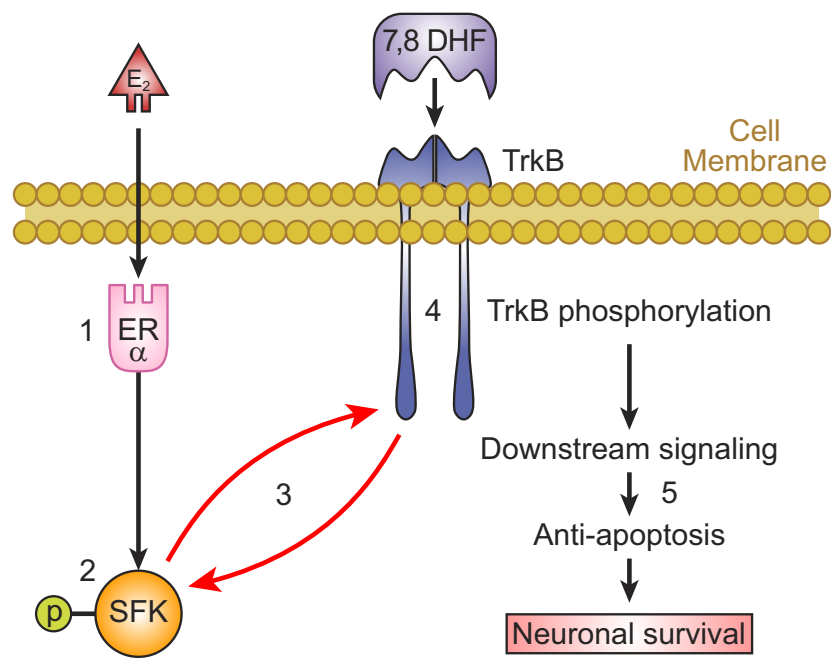

Figure 9. Crosstalk between the ER $\alpha$ and TrkB post-HI. (1) HI induces $\mathrm{ER} \alpha$ expression in neonatal hippocampal cells, which are thereafter activated by circulating or neural-derived estradiol $\left(E_{2}\right)$. (2) $E R \alpha$ signaling prompts activation of SFK, and (3) SFK enhance phosphorylation and hence, enhance activation of TrkB receptors in response to (4) TrkB receptor ligands resulting in (5) decreased apoptosis and increased neuronal survival.

male mice after adult $\mathrm{HI}$ (Han et al., 2012) or TBI (Longo and Massa, 2013). The TrkB agonist antibody (27D7) pretherapy enhances hippocampal neuronal survival and improves the long-term sensory motor function post-HI in neonatal rats (Kim et al., 2014). However, these studies did not investigate any role for sex differences in their neuroprotective outcomes. They were conducted either only in male animals or in pooled brains obtained from both males and females. In contrast, it has been reported that activation of TrkB with 7,8-DHF confers neuroprotection in female neonatal mice post-HI but not in males and this sex difference persists into adulthood as determined by hippocampal-dependent memory and learning at P60 (Uluc et al., 2013). In this study, we confirm the findings of Uluc et al. (2013) and report that the female neonate hippocampus has statistically significantly higher levels of TrkB phosphorylation with 7,8-DHF therapy post-HI. This effect was not found to be attributed to the TrkB subtypes such as to the t-TrkB, which can act as a dominantnegative inhibitor of $f-T r k B$ and prevent $f-T r k B$ from getting phosphorylated (Fenner, 2012). Together, our data suggest that $\mathrm{HI}$ and 7,8-DHF therapy increases hippocampal $p$-TrkB expression in a sexually differentiated manner and that the increased hippocampal p-TrkB expression is associated with increased hippocampal ER $\alpha$ expression.

\section{Hippocampal TrkB phosphorylation depends on the presence of the ER $\alpha$}

Estradiol therapy has been shown to increase the hippocampal TrkB phosphorylation in adult mice, but this response is ablated in ER $\alpha^{-/-}$mice (Spencer-Segal et al.,
2012). We therefore tested the hypothesis that the sexually differentiated increase in hippocampal TrkB phosphorylation in the neonate following $\mathrm{HI}$ is a consequence of increased $\mathrm{ER} \alpha$ signaling (Fig. 9). We found that $\mathrm{HI}$ and 7,8-DHF therapy failed to increase the hippocampal $\mathrm{p}$-TrkB levels in $\mathrm{ER} \alpha^{-1-}$ mice $3 \mathrm{~d}$ post-HI. These results clearly demonstrate that the hippocampal TrkB phosphorylation depends upon the presence of $\operatorname{ER} \alpha$. When coupled with the observation that $\mathrm{ER} \alpha$ expression is greater in the female hippocampus post-HI, these findings provide strong evidence that the sexually differentiated pattern of phosphorylation of TrkB following $\mathrm{HI}$ and after TrkB agonist therapy is mediated by $\mathrm{ER} \alpha$. The hippocampal $\mathrm{E}_{2}$ action could be exerted through increased production of a TrkB ligand or through stimulation of intracellular signaling pathways following $\mathrm{HI}$ in neonatal brains (McDevitt et al., 2008; Levin, 2014). To test the first possibility, we measured the hippocampal BDNF mRNA levels as an indirect indication of the nuclear $\mathrm{ER} \alpha$ signaling in neonatal mice following $\mathrm{HI}$. Our findings showed that hippocampal BDNF mRNA levels decreased in the female hippocampus compared with male hippocampus. This result suggests that the first possibility of $E_{2}$ inducing increased production of intrinsic TrkB ligand via classical pathway cannot be held responsible for increased TrkB phosphorylation. Thus, we hypothesized that the crosstalk between the $\mathrm{ER} \alpha$ and TrkB is through the cytoplasmic kinase signaling after rapid membrane $\mathrm{ER} \alpha$ activation.

\section{Crosstalk between ER $\alpha$ and TrkB might be mediated by $\mathrm{p}$-src in neonatal hippocampus post-HI}

One possible mechanism that can link the $\mathrm{ER} \alpha$ with TrkB is that $\mathrm{ER} \alpha$ can couple to the cytoplasmic SFKs through the membrane initiated signaling resulting in phosphorylation of the TrkB (Levin, 2012). Using mixed neuronal/glial cortical cultures, Huang et al. demonstrated that the SFKs can directly phosphorylate $\mathrm{TrkB}^{\mathrm{Y705/Y706}}$. In addition, the fact that TrkB immunoprecipitates with both src and fyn confirms a physical relationship between these kinases and TrkB (Huang and McNamara, 2010). Our results are consistent with a role for membrane-initiated rapid signaling of $\mathrm{ER} \alpha$. The expression of $\mathrm{p}$-src significantly increases in female hippocampus compared with males following $\mathrm{HI}$ and 7,8-DHF therapy. This sex difference seen in p-src expression in the hippocampus is totally ablated in $\mathrm{ER} \alpha^{-1-}$ mice. Thus, increases in ER $\alpha$ expression in female hippocampus could lead to increases in signaling through p-src, which could facilitate phosphorylation of TrkB and promote downstream anti-apoptotic signaling post-HI (Fig. 9).

\section{TrkB agonist therapy decreases apoptosis in female hippocampus post-HI}

The mechanisms underlying the sex differences in neonatal brains post-HI is unknown. Recent experiments into sexdependent cell death pathways in neonates have led to a hypothesis that in females cell death occurs primarily through a caspase-dependent pathway, whereas in males it is secondary to PARP activation post-HI (Lang and McCullough, 2008). Genetic deletion of PARP protected males but not females post-HI in P7 mice (Hagberg et al., 2004). 
Thus, Renolleau et al. (2007) reported that c-caspase-3 in females is elevated $1 \mathrm{~d}$ post- $\mathrm{HI}$ in the cortex of $\mathrm{P} 7$ rats and that the pan-caspase inhibitor Q-VD-OPh is neuroprotective in females, but not in males. In our study, unlike the results of Renolleau et al. (2007), we detected higher c-caspase-3 protein expression in male hippocampus compared with females at $1 \mathrm{~d}$ post-HI. The reason for this apparent discrepancy could be the result of sex differences in regional caspase expression postinjury (hippocampus vs cortex), although further studies are required to confirm this finding. Consistent with our hypothesis, TrkB agonist therapy resulted in a significant decrease in C-caspase-3 in female hippocampus, but not in males. In addition, c-caspase-3 expression increased in the female $\mathrm{ER} \alpha^{-\prime-}$ mice hippocampus and 7,8-DHF therapy did not have any effects decreasing the apoptosis. In contrast, neither 7,8-DHF therapy nor $\mathrm{ER} \alpha$ deletion changed c-caspase-3 expression in the male hippocampus. This could be the result of different apoptotic pathways present in the male hippocampus that may not be caspase dependent. Future studies are required to elucidate that relationship between sex-dependent cell death pathways and $\mathrm{ER} \alpha$-dependent neurotrophin signaling.

\section{Conclusion}

To our knowledge, this is the first study to reveal that hippocampal $\mathrm{ER} \alpha$ signaling is integrated with TrkB signaling in a manner that it is more robust in neonatal females, potentially accounting for the sex differences seen after HI-related brain injury. We have shown that genetic deletion of $\mathrm{ER} \alpha$ abolishes the sexually differentiated expression of $p$-TrkB in response to its agonist, 7-8, DHF, in neonatal mice post-HI. In addition, we demonstrated that there is a sex difference in the post-HI activation of $\mathrm{p}$-src in neonatal hippocampus that is also $\mathrm{ER} \alpha$ dependent. Thus, increased $\mathrm{ER} \alpha$ signaling through src in female hippocampus that facilitates TrkB signaling resulting in decreased c-caspase-3 is a novel mechanism that could account for the sex differences in brain injury following $\mathrm{HI}$ in neonates. Better understanding of the mechanisms involved in female resistance to injury could lead to targeted therapies in neonates following hypoxic and ischemic encephalopathy.

\section{References}

Almli CR, Levy TJ, Han BH, Shah AR, Gidday JM, Holtzman DM (2000) BDNF protects against spatial memory deficits following neonatal hypoxia-ischemia. Exp Neurol 166:99-114. CrossRef Medline

Arpino G, Wiechmann L, Osborne CK, Schiff R (2008) Crosstalk between the estrogen receptor and the HER tyrosine kinase receptor family: molecular mechanism and clinical implications for endocrine therapy resistance. Endocr Rev 29:217-233. CrossRef Medline

Barletta F, Wong CW, McNally C, Komm BS, Katzenellenbogen B, Cheskis BJ (2004) Characterization of the interactions of estrogen receptor and MNAR in the activation of cSrc. Mol Endocrinol 18:1096-1108. CrossRef Medline

Bothwell M (2014) NGF, BDNF, NT3, and NT4. Handb Exp Pharmacol 220:3-15. CrossRef Medline

Cazorla M, Arrang JM, Prémont J (2011) Pharmacological characterization of six trkB antibodies reveals a novel class of functional agents for the study of the BDNF receptor. Br J Pharmacol 162: 947-960. CrossRef Medline

Cengiz P, Kleman N, Uluc K, Kendigelen P, Hagemann T, Akture E, Messing A, Ferrazzano P, Sun D (2011) Inhibition of $\mathrm{Na}+/ \mathrm{H}+$ exchanger isoform 1 is neuroprotective in neonatal hypoxic ischemic brain injury. Antiox Redox Signal 14:1803-1813. CrossRef Medline

Chen A, Xiong LJ, Tong Y, Mao M (2013) The neuroprotective roles of BDNF in hypoxic ischemic brain injury. Biomed Rep 1:167-176. CrossRef Medline

Devi L, Ohno M (2012) 7,8-dihydroxyflavone, a small-molecule TrkB agonist, reverses memory deficits and BACE1 elevation in a mouse model of Alzheimer's disease. Neuropsychopharmacology 37:434-444. CrossRef Medline

Donders J, Hoffman NM (2002) Gender differences in learning and memory after pediatric traumatic brain injury. Neuropsychology 16:491-499. Medline

Drobyshevsky A, Derrick M, Wyrwicz AM, Ji X, Englof I, Ullman LM, Zelaya ME, Northington FJ, Tan S (2007) White matter injury correlates with hypertonia in an animal model of cerebral palsy. $J$ Cereb Blood Flow Metab 27:270-281. CrossRef

Dubal DB, Zhu H, Yu J, Rau SW, Shughrue PJ, Merchenthaler I, Kindy MS, Wise PM (2001) Estrogen receptor alpha, not beta, is a critical link in estradiol-mediated protection against brain injury. Proc Natl Acad Sci U S A 98:1952-1957. CrossRef

Fang AY, Gonzalez FF, Sheldon RA, Ferriero DM (2013) Effects of combination therapy using hypothermia and erythropoietin in a rat model of neonatal hypoxia-ischemia. Pediatr Res 73:12-17. CrossRef Medline

Fenner BM (2012) Truncated TrkB: beyond a dominant negative receptor. Cytokine Growth Factor Rev 23:15-24. CrossRef Medline

Ferriero DM (2004) Neonatal brain injury. N Engl J Med 351:19851995. CrossRef Medline

Golder FJ, Ranganathan L, Satriotomo I, Hoffman M, Lovett-Bar MR, Watters JJ, Baker-Herman TL, Mitchell GS (2008) Spinal adenosine A2a receptor activation elicits long-lasting phrenic motor facilitation. J. Neurosci 28:2033-2042

Hagberg $\mathrm{H}$, Wilson MA, Matsushita H, Zhu C, Lange M, Gustavsson M, Poitras MF, Dawson TM, Dawson VL, Northington F, Johnston MV (2004) PARP-1 gene disruption in mice preferentially protects males from perinatal brain injury. J Neurochem 90:1068-1075. CrossRef Medline

Han BH, D'Costa A, Back SA, Parsadanian M, Patel S, Shah AR, Gidday JM, Srinivasan A, Deshmukh M, Holtzman DM (2000) BDNF blocks caspase-3 activation in neonatal hypoxia-ischemia. Neurobiol Dis 7:38-53. CrossRef Medline

Han J, Pollak J, Yang T, Siddiqui MR, Doyle KP, Taravosh-Lahn K, Cekanaviciute E, Han A, Goodman JZ, Jones B, Jing D, Massa SM, Longo FM, Buckwalter MS (2012) Delayed administration of a small molecule tropomyosin-related kinase B ligand promotes recovery after hypoxic-ischemic stroke. Stroke 43:1918-1924. CrossRef Medline

Hill CA, Fitch RH (2012) Sex differences in mechanisms and outcome of neonatal hypoxia-ischemia in rodent models: implications for sex-specific neuroprotection in clinical neonatal practice. Neurol Res Int 2012:1-9. CrossRef

Hilton GD, Nuñez JL, McCarthy MM (2003) Sex differences in response to kainic acid and estradiol in the hippocampus of newborn rats. Neuroscience 116:383-391. CrossRef

Huang EJ, Reichardt LF (2001) Neurotrophins: roles in neuronal development and function. Annual review of neuroscience 24:677736. CrossRef Medline

Huang YZ, McNamara JO (2010) Mutual regulation of Src family kinases and the neurotrophin receptor TrkB. J Biol Chem 285: 8207-8217. CrossRef Medline

Husson I, Rangon CM, Lelievre V, Bemelmans AP, Sachs P, Mallet J, Kosofsky BE, Gressens P (2005) BDNF-induced white matter neuroprotection and stage-dependent neuronal survival following a neonatal excitotoxic challenge. Cereb Cortex 15:250-261.

Jang SW, Liu X, Yepes M, Shepherd KR, Miller GW, Liu Y, Wilson WD, Xiao G, Blanchi B, Sun YE, Ye K (2010) A selective TrkB agonist with potent neurotrophic activities by 7,8-dihydroxyflavone. Proc Nat Acad Sci U S A 107:2687-2692. CrossRef Medline 
Kim GS, Cho S, Nelson JW, Zipfel GJ, Han BH (2014) TrkB agonist antibody pretreatment enhances neuronal survival and long-term sensory motor function following hypoxic ischemic injury in neonatal rats. Plos One 9:88962. CrossRef

Lang JT, McCullough LD (2008) Pathways to ischemic neuronal cell death: are sex differences relevant? J Transl Med 6:33. CrossRef Medline

Levin ER (2012) Elusive extranuclear estrogen receptors in breast cancer. Clin Cancer Res 18:6-8. CrossRef Medline

Levin ER (2014) Extranuclear estrogen receptor's roles in physiology: lessons from mouse models. Am J Physiol Endocrinol Metab 307:E133-E140. CrossRef Medline

Liu Y, Rutlin M, Huang S, Barrick CA, Wang F, Jones KR, Tessarollo L, Ginty DD (2012) Sexually dimorphic BDNF signaling directs sensory innervation of the mammary gland. Science 338:13571360. CrossRef Medline

Longo FM, Massa SM (2013) Small-molecule modulation of neurotrophin receptors: a strategy for the treatment of neurological disease. Nat Rev Drug Discov 12:507-525. Medline

Marlow N, Rose AS, Rands CE, Draper ES (2005) Neuropsychological and educational problems at school age associated with neonatal encephalopathy. Arch Dis Child Fetal Neonatal Ed 90: F380-F387. CrossRef Medline

McDevitt MA, Glidewell-Kenney C, Jimenez MA, Ahearn PC, Weiss $\mathrm{J}$, Jameson JL, Levine JE (2008) New insights into the classical and non-classical actions of estrogen: evidence from estrogen receptor knock-out and knock-in mice. Mol Cell Endocrinol 290: 24-30. CrossRef Medline

Minichiello L (2009) TrkB signalling pathways in LTP and learning. Nat Rev Neurosci 10:850-860. CrossRef Medline

Miranda RC, Sohrabji F, Toran-Allerand D (1994) Interactions of estrogen with the neurotrophins and their receptors during neural development. Horm Behav 28:367-375. CrossRef Medline

Mujsce DJ, Christensen MA, Vannucci RC (1990) Cerebral blood flow and edema in perinatal hypoxic-ischemic brain damage. Pediatr Res 27:450-453. CrossRef Medline

Muller MM, Middelanis J, Meier C, Surbek D, Berger R (2013) $17 \beta$ estradiol protects 7-day old rats from acute brain injury and reduces the number of apoptotic cells. Reprod Sci 20:253-261. CrossRef Medline

Nelson KB, Lynch JK (2004) Stroke in newborn infants. Lancet Neurol 3:150-158. CrossRef Medline

Pérez SE, Chen EY, Mufson EJ (2003) Distribution of estrogen receptor alpha and beta immunoreactive profiles in the postnatal rat brain. Brain Res Dev Brain Res 145:117-139. Medline

Poduslo JF, Curran GL (1996) Permeability at the blood-brain and blood-nerve barriers of the neurotrophic factors: NGF, CNTF, NT-3, BDNF. Brain Res Mol Brain Res 36:280-286. Medline

Renolleau S, Fau S, Goyenvalle C, Joly LM, Chauvier D, Jacotot E, Mariani J, Charriaut-Marlangue C (2007) Specific caspase inhibitor Q-VD-OPh prevents neonatal stroke in P7 rat: a role for gender. J Neurochem 100:1062-1071. CrossRef Medline

Rutter M, Caspi A, Moffitt TE (2003) Using sex differences in psychopathology to study causal mechanisms: unifying issues and research strategies. J Child Psychol Psychiatry 44:1092-1115. Medline

Scharfman HE, Maclusky NJ (2005) Similarities between actions of estrogen and BDNF in the hippocampus: coincidence or clue? Trends Neurosci 28:79-85. CrossRef Medline

Schneider CA, Rasband WS, Eliceiri KW (2012) NIH Image to ImageJ: 25 years of image analysis. Nat Methods 9:671-675. Medline
Schreihofer DA, Ma Y (2013) Estrogen receptors and ischemic neuroprotection: who, what, where, and when? Brain Res 1514:107122. CrossRef Medline

Simerly RB, Zee MC, Pendleton JW, Lubahn DB, Korach KS (1997) Estrogen receptor-dependent sexual differentiation of dopaminergic neurons in the preoptic region of the mouse. Proc Natl Acad Sci U S A 94:14077-14082. Medline

Solum DT, Handa RJ (2002) Estrogen regulates the development of brain-derived neurotrophic factor mRNA and protein in the rat hippocampus. J Neurosci 22:2650-2659. Medline Medline

Spencer-Segal JL, Tsuda MC, Mattei L, Waters EM, Romeo RD, Milner TA, McEwen BS, Ogawa S (2012) Estradiol acts via estrogen receptors alpha and beta on pathways important for synaptic plasticity in the mouse hippocampal formation. Neuroscience 202: 131-146. CrossRef Medline

Suzuki S, Brown CM, Wise PM (2009) Neuroprotective effects of estrogens following ischemic stroke. Front Neuroendocrinol 30: 201-211. CrossRef Medline

Thorne RG, Frey WH 2nd (2001) Delivery of neurotrophic factors to the central nervous system: pharmacokinetic considerations. Clin Pharmacokinet 40:907-946. CrossRef Medline

Tioseco JA, Aly H, Essers J, Patel K, El-Mohandes AA (2006) Male sex and intraventricular hemorrhage. Pediatr Crit Care Med 7:4044. Medline

Uluc K, Kendigelen P, Fidan E, Zhang L, Chanana V, Kintner D, Akture E, Song C, Ye K, Sun D, Ferrazzano P, Cengiz P (2013) TrkB receptor agonist 7,8 dihydroxyflavone triggers profound genderdependent neuroprotection in mice after perinatal hypoxia and ischemia. CNS Neurol Disord Drug Targets 12:360-370. Medline

Vannucci RC, Vannucci SJ (1997) A model of perinatal hypoxicischemic brain damage. Ann N Y Acad Sci 835:234-249. Medline

Vannucci SJ, Hurn PD (2009) Gender differences in pediatric stroke: is elevated testosterone a risk factor for boys? Ann Neurol 66:713714. CrossRef Medline

Waterhouse EG, An JJ, Orefice LL, Baydyuk M, Liao GY, Zheng K, Lu $B, X u$ B (2012) BDNF promotes differentiation and maturation of adult-born neurons through GABAergic transmission. J Neurosci 32:14318-14330. CrossRef Medline

Westberry JM, Prewitt AK, Wilson ME (2008) Epigenetic regulation of the estrogen receptor alpha promoter in the cerebral cortex following ischemia in male and female rats. Neuroscience 152:982989 CrossRef Medline

Westberry JM, Trout AL, Wilson ME (2010) Epigenetic regulation of estrogen receptor alpha gene expression in the mouse cortex during early postnatal development. Endocrinology 151:731-740. CrossRef Medline

Wilson ME, Westberry JM (2009) Regulation of oestrogen receptor gene expression: new insights and novel mechanisms. J Neuroendocrinol 21:238-242. CrossRef Medline

Wilson ME, Westberry JM, Trout AL (2011) Estrogen receptor-alpha gene expression in the cortex: sex differences during development and in adulthood. Horm Behav 59:353-357. CrossRef Medline

Witty CF, Gardella LP, Perez MC, Daniel JM (2013) Short-term estradiol administration in aging ovariectomized rats provides lasting benefits for memory and the hippocampus: a role for insulin-like growth factor-l. Endocrinology 154:842-852. CrossRef Medline

Zeng Y, Wang X, Wang Q, Liu S, Hu X, McClintock SM (2013) Smal molecules activating TrkB receptor for treating a variety of CNS disorders. CNS Neurol Disord Drug Targets 12:1066-1077. Medline 